\title{
Resources, Navigation, and Punishment in the Criminal Courts
}

\author{
Matthew Clair \\ University of Pennsylvania Law School \\ mattclair@law.upenn.edu
}

Draft Date: October 2018

\begin{abstract}
This paper considers how criminal defendants make consequential decisions during court processing. Drawing on interviews and ethnographic observations among a racially and socio-economically diverse sample of Boston-area defendants and among legal officials, the author describes defendants' differential styles of engagement with lawyers and the court. Whereas defendants who have reason to trust their lawyers often delegate legal authority to them in consequential moments and experience relative ease of court navigation as a result, defendants who have reason to mistrust their lawyers often withdraw from lawyers and seek to acquire their own legal expertise, such as knowledge about criminal law and procedure learned in their communities, in jail, and through observation. Defendants' assertive use of self-acquired expertise, however, is discouraged by the court system, often drawing punitive responses from legal officials and constraining defendants' legal choices. Thus, the cultural styles and resources that scholars have shown to benefit the privileged in mainstream institutions such as schools and workplaces have negative repercussions in the criminal courts, often to the detriment of lessadvantaged defendants. The author discusses implications for research on criminal court disparities and sociological theory on culture, expertise, and navigation across a range of institutions.
\end{abstract}

Acknowledgments: For their comments, I thank Asad L. Asad, Lawrence D. Bobo, Bart Bonikowski, Sherelle Ferguson, Peter Francis Harvey, Kimberly Kay Hoang, Anthony Abraham Jack, Hyejeong Jo, Michèle Lamont, Annette Lareau, Devah Pager, Robert Vargas, Alba Villamil, Bruce Western, Alix S. Winter, and Amanda Woog. Feedback from audiences at Stanford University, George Washington University, Brown University, the University of Pennsylvania, New York University, Colby College, the University of Chicago, the State University of New York at Albany, the University of Michigan, Yale University, the American Society of Criminology, the American Sociological Association, and the Law \& Society Association proved helpful in thinking through this paper's argument and evidence. I also thank the Massachusetts legal professionals who have shared their confidence, time, and resources. Finally, I am indebted to the people whose experiences are at the heart of this research. This research has been supported by the National Science Foundation (Grant no. DGE1144152), the Harvard Merit/Term-Time Fellowship, the Quattrone Center Research Fellowship, the Ruth D. Peterson Fellowship for Racial and Ethnic Diversity, and the University of Pennsylvania Pre-Doctoral Fellowship for Excellence through Diversity. 


\section{INTRODUCTION}

Sociologists have long documented inequality in institutional settings. The criminal courts are no exception. Writing at the turn of the twentieth century, the earliest American sociologists and criminologists documented the outsized presence of poor people, white immigrants, and African Americans in the courthouses and jails of major cities (Du Bois 1996 [1899]; Sellin 1928). In recent decades, researchers have relied on qualitative analyses of courthouse cultures from the perspective of legal officials and quantitative analyses of administrative data to develop and test explanations for the persistence of inequalities in myriad court outcomes, including pre-trial detainment, conviction, incarceration, and sentence length (Baumer 2013; Spohn 2013; Ulmer 2012). While these empirical examinations have documented the role of lawyers, judges, and facially-neutral laws in reproducing race and class inequality, such accounts often sideline the perspective of an important actor in the courts: the criminal defendant. How do defendants navigate within these constraints?

This paper examines how criminal defendants understand and engage with the criminal court process, focusing on their interactions with their lawyers and their uses of legal expertise during consequential court processing moments. Drawing on interviews and ethnographic observations among a racially and socio-economically diverse sample of defendants and legal officials, I show how defendants' decision-making is influenced by the trustworthiness of their lawyers and their access to self-acquired legal expertise about criminal law and procedure. I find that defendants who have reason to trust their lawyers often delegate authority to them in consequential moments and experience relative ease of court navigation as a result. In contrast, defendants who have reason to mistrust their lawyers often withdraw from lawyers and seek to acquire their own forms of legal expertise, such as knowledge about criminal law and procedure learned in their communities, in jail, and through observation. Defendants' assertive use of selfacquired expertise draws punitive responses from legal officials and constrains their legal choices. These processes often unfold to the detriment of less-advantaged defendants, given their lack of access to lawyers they trust and skepticism of legal officials' incentives.

These findings have implications for research on criminal court disparities and sociological theory on culture, expertise, and institutional navigation. In particular, the consequences of defendants' differential navigation of the criminal courts contrasts with sociological findings on individuals' navigation of more mainstream institutions, such as schools and workplaces. In these latter institutions, demanding and assertive cultural styles of engagement and the accrual of institutional knowledge have been shown to be rewarded rather than punished by institutional authorities (Calarco 2014; Lareau 2011, 2015; Stephens, Markus, Phillips 2013; Streib 2011). Contrasting navigation of the courts with that of other institutions not only lays bare the implicit — and uniquely punitive — rules of the game of the criminal courts but also motivates future research on the distinctive cultural styles and resources that may constrain navigation across a range of institutions and professional-client relationships.

\section{THE MISSING CRIMINAL DEFENDANT}

Contemporary research on criminal court processing has provided important insight into the role of the law and of legal officials in shaping court punishment. In particular, ethnographic and interview-based studies have documented how legal officials' cultures and decisions structure court processing and shape defendants' outcomes. Abraham Blumberg's (1967) now-classic 
book Criminal Justice was one of the earliest ethnographies to provide an empirical description of an American criminal court as it operated on the ground. Drawing on data from a large metropolitan court system, he showed how defense attorneys and prosecutors engaged in "justice by negotiation," whereby they relied on plea deals to efficiently dispose of cases. He argued that defense attorneys used "modes of coercion and influence" (Blumberg 1967, p. 21)—such as encouraging their clients to plead-in order to keep the court bureaucracy running smoothly. These findings contrasted sharply with the assumptions of scholars and journalists of the earlytwentieth century who had often portrayed the courts as a system of adversarial trials, in which defense attorneys actively contested prosecutors on behalf of defendants, who also leveraged their own resources to contest the law. Instead, Blumberg argued that a defendant's "social position" (i.e., education, occupation, or income) could not overcome the coercion of the bureaucratic court process - a finding that he argued is "contrary to a rather shopworn notion among criminologists" (Blumberg 1967, p. 41).

While some scholars have critiqued elements of Blumberg's analysis (e.g., Eisenstein and Jacob 1977; Feeley 1992 [1979]; Heumann 1978), much recent research on court cultures has largely confirmed Blumberg's central insights about coercion and a lack of adversarialism across myriad court settings (Flemming 1986; Kohler-Hausmann 2013; Lynch 2016; Mather 1979; Van Cleve 2016). For instance, Eisenstein and Jacob (1977) critique Blumberg's description of courts as bureaucracies, noting that they are not hierarchically organized and that defendants' cases receive some individualized treatment. Nevertheless, similar to Blumberg, Eisenstein and Jacob find that defense attorneys feel pressure to control their clients, given misaligned incentives, such as state funding on the basis of efficient case disposal (see also Flemming 1986; Schulhofer and Friedman 1993). For his part, Feeley (1992 [1979]) critiques Blumberg's notion that a preponderance of plea deals in courts necessarily suggests a lack of adversarialism. He shows that pleas involve adversarial processes tied to negotiations, motions, and other "thoughtful examinations" by defense attorneys, prosecutors and judges seeking to develop a common understanding of the facts of a case (Feeley 1992 [1979], p. 13-29). Feeley's analysis centers on the role of legal officials in these negotiation processes (see also Heumann 1978); yet, he leaves open the possibility of defendants' participation, writing: "The interests of the accused can also shape the outcome of a case. Many defendants are intense, and willing to do whatever is necessary to avoid conviction or minimize their sentence" (Feeley 1992 [1979], p. 152; see also Mather 1979, p. 10).

How do defendants operate within these cultural and structural constraints? While foundational court ethnographies tend to portray defendants as background players who are acted upon, a number of studies have examined defendants' attitudes about court processing. Scholars have examined defendants' perceptions of their legal outcomes (e.g., Boccaccini, Boothby, and Brodsky 2004; Tyler 1984), their preferred legal outcomes (e.g., Boccaccini and Brodsky 2001; Petersilia 1990; Wood and May 2003), and their lawyers (e.g., Boccaccini et al. 2004; Casper 1972; O'Brien et al. 1977; Wilkerson 1972). This research focus on defendants' perspectives has uncovered important realities about court processing largely missing from research that centers on the perspective of legal officials. For instance, scholarship on defendants' attitudes about lawyers has found that many defendants have negative feelings toward court-appointed attorneys (Boccaccini and Brodsky 2001; Casper 1972; O'Brien et al. 1977; Wilkerson 1972) and perceive that such attorneys pressure them to take plea deals against their best interests (Wilkerson 1972). Meanwhile, defendants who retain private attorneys have been shown to exhibit higher levels of trust in their lawyers (Casper 1972) and a greater belief in their lawyers' legal competence 
(O'Brien et al. 1977). Higher levels of trust have also been found to be associated with defendants' perceptions that their lawyers (whether they be court-appointed or privately retained) allowed them to participate in their own legal defense (Boccaccini et al. 2004).

Yet, far less empirical research examines defendants' ways of engaging with the court process despite a clear assumption in legal scholarship and criminal procedure that defendants must make myriad court processing decisions - from the choice of counsel, privileged conversations with attorneys, and consenting to pre-trial strategy to choosing trial versus plea, deciding to take the witness stand, and consenting to sentencing alternatives (see Schulhofer and Friedman 1993; Spiegel 1979; Uphoff 2000; Uphoff and Wood 1998). ${ }^{1}$ An exception is Jonathan D. Casper's (1972) book American Criminal Justice: The Defendant's Perspective. Although the study largely examines defendants' attitudes, it remains as one of the few to also offer some insight into defendants' ways of engaging (or not) with court processing. Drawing on interviews among defendants who faced felony charges in Connecticut, Casper finds that the mostly white and poor men in his sample view the courts as an extension of their life on the streets (Casper 1972, p. 81). Like the streets, the system requires that they exploit the few resources at their disposal to hustle a deal that is less-harsh than a sentence they might otherwise receive for the same charge. Yet, Casper describes most defendants in his study as resigned to their fates - and therefore frames their beliefs, perspectives, and strategies as largely inconsequential in shaping their court experiences. According to Casper, defendants' distrust of their lawyers combined with their lack of knowledge about certain legal defenses and their readiness to acknowledge their factual guilt results in resignation and little engagement with the legal process. Similarly, drawing on interviews among a sample of incarcerated men in Arkansas, Boccaccini and Brodsky (2001, pp. 102-103) found that most former defendants were unsatisfied with their former lawyers and recounted that, if they had been provided with an "ideal attorney," they would have "act[ed] differently" by being more honest with their lawyers and more willing to share important information about their cases. These two studies provide some insight into how defendants not only think about but also engage with the court process.

An important limitation of existing work on both defendants' attitudes and engagement is the lack of racial and socioeconomic variation ${ }^{2}$ among the defendants sampled, given that most research samples from incarcerated populations. ${ }^{3}$ Whereas qualitative research from the perspective of legal officials (e.g., judges and lawyers) has increasingly considered their own race and class biases and identities and how such characteristics may influence their decisionmaking (e.g., Bridges and Steen 1998; Clair and Winter 2016; Emmelman 1994; Van Cleve 2016), researchers have yet to consider whether defendants' race and class social locations shape their perspectives and actions. At the same time, quantitative analyses of administrative data routinely measure race and class outcomes among defendants. This line of research has found mixed evidence that a defendant's race (Mitchell 2005; Spohn 2000; Zatz 2000) and socioeconomic status (Zatz 2000) is directly associated with unequal court outcomes, net of legal

\footnotetext{
${ }^{1}$ For theoretical considerations of defendants' ways of engaging with criminal court processing, see Black (1989) and Mather (2003). For legal scholarship debating the proper role of defendants' decision-making within the attorney-client relationship, see Natapoff (2005), Spiegel (1979), and Uphoff (2000).

${ }^{2}$ Whereas Casper (1972) interviewed mostly white and poor men and Boccaccini et al. (2004) interviewed mostly black men, other studies do not even present the racial or socio-economic characteristics of the individuals in their sample (e.g., Boaccaccini and Brodsky 2001; O’Brien et al. 1977).

${ }^{3}$ Selecting respondents primarily from incarcerated populations (e.g., Boccaccini et al. 2004; Boccaccini and Brodsky 2001; Casper 1972; O'Brien et al. 1977) misses the majority of criminal defendants - particularly socioeconomically advantaged ones - who do not face jail or prison time (on a similar point, see Wilkerson 1972, p. 142).
} 
factors. For instance, direct race or class effects have been observed at bail/pretrial release (Chiricos and Bales 1991; Demuth 2003; Kutateladze et al. 2014; Schelsinger 2005), at the decision to dismiss or reduce charges (Spohn, Gruhl, and Welch 1987; Shermer and Johnson 2009), and at sentencing (Chiricos and Bales 1991; De'Alessio and Stolzenberg 1993; Johnson and DiPietro 2012; Kutateladze et al. 2014; Nobiling, Spohn, and DeLone 1998; Shermer and Johnson 2009). While such evidence varies by jurisdiction (see Baldus, Pulaski, and Woodworth 1986; Johnson 2006) and crime type (Mitchell 2005), these studies provide cumulative evidence of the unequal treatment of similarly-situated defendants by race and class. Scholars continue to debate the causes of these observed inequalities (Baumer 2013; Clair 2018; Spohn 2000; Ulmer 2012).

\section{CULTURE AND INSTITUTIONAL NAVIGATION}

To examine how a racially and socio-economically diverse sample of defendants engages with court processing, I employ insights from sociological research on how everyday people from different backgrounds navigate other institutions, such as schools and the workplace. This literature provides useful theoretical tools to conceptualize how defendants interact with their lawyers, how their interactions are shaped by structural conditions, and how institutional rules and authorities ultimately reward certain cultural styles of engagement while punishing others.

Sociologists have increasingly moved beyond studying purposeful discrimination by individuals in power to studying how institutional processes reproduce inequality in often subtle ways (see Lamont, Beljean, and Clair 2014; Pager and Shepherd 2008; Tilly 1998). Cultural sociologists and social psychologists, in particular, have shown how micro-level interactions within institutions shape - and are shaped by — cultural and social processes in broader society (Fiske and Markus 2012; Lamont et al. 2014; Ridgeway 2014; Schwalbe 2000). While these processes often appear standardized and neutral, symbolic power imbalances often undergird them. Lamont and Lareau (1988, p. 159) define symbolic power as the power "of legitimating the claim that specific cultural norms and practices are superior, and of institutionalizing these claims to regulate behavior and access to resources." In other words, those in power define the rules of the game with respect to micro-level (Collins 1981; Goffman 1967) and institutional (Bourdieu 1987; Lareau 2015) interactions. Certain cultural resources and styles are rewarded or penalized (and thus a basis of inclusion or exclusion) because they are characteristic of certain privileged or disadvantaged social positions (Lamont and Lareau 1988).

Sociologists studying interactions within institutions have documented how cultural resources (e.g., knowledge of cultural objects, educational credentials, or organizational procedures) and cultural styles (e.g., skills, habits, dispositions, or ways of speaking) matter in shaping successful navigation of educational, labor market, and, increasingly, health care institutions (Bourdieu 1987; Bourdieu and Passeron 1977; Lareau 2015; Rivera 2015; Shim 2010). ${ }^{4}$ While this research literature is large and diverse, a central finding is that middle-class individuals tend to exhibit cultural styles that are individualistic, entitled, and demanding in their institutional encounters, whereas working-class and poor individuals tend to exhibit cultural styles of deference (Stephens, Markus, Phillips 2013; see e.g., Calarco 2014; Lareau 2011; Streib

\footnotetext{
${ }^{4}$ On the general distinction between resources and styles/schemas, see Sewell (1992). Sewell argues that cultural schemas (defined as habits, styles and rules of behavior) shape and are shaped by resources (defined as human and nonhuman objects that are used to maintain power; e.g., knowledge, money, or raw materials). Some scholars refer to both cultural resources and styles as forms of cultural capital (see Lareau 2015).
} 
2011). Therefore, in addition to having greater access to educational credentials, cultural knowledge, social ties, and money, the middle class also exhibits demanding and assertive cultural styles that have been shown to be aligned with the institutional expectations of schools and employers (Lareau 2015). Because cultural styles must be accepted by specific institutional authorities to result in social profits, some sociologists have argued that the same cultural style or resource may be rewarded in one context but not in another (see Carter 2003; Young 1999). Moreover, some scholars argue that social mobility is possible for those in less-advantaged social positions through the acquisition of institutionally-valued forms of cultural resources and styles (see Carter 2003; Jack forthcoming).

Most scholarship on unequal institutional navigation has focused on common institutions such as schools, workplaces, and, to a lesser extent, health care providers; meanwhile, research in other institutional domains, such as the criminal justice system, has rarely considered how cultural resources and styles may shape differences in navigation across social groups. Research on legal consciousness trends in this direction. Unlike research on people's legal attitudes (e.g., Tyler 1984), legal consciousness research considers people's cultural styles - not just their attitudes - with respect to the law and how such styles reproduce the law's hegemony (Ewick and Silbey 1998, p. 38-9; Silbey 2005, p. 334). But research in this tradition has yet to consider legal consciousness in the criminal courts, focusing instead on everyday legal interactions such as writing contracts and dealing with neighbors (Ewick and Silbey 1998), social activism (see Silbey 2005), and police-citizen interactions (Young 2014).

Moreover, other cultural accounts of criminal justice institutions-also often focused on policing as opposed to court processing (but see Mears et al. 2017) — are overwhelmingly understood through the lens of the (often, urban and black) poor without reference to more advantaged individuals (e.g., Duck 2015; Goffman 2014; Mears et al. 2017; Rios 2011; Stuart 2016; Young 2014). Scholars have far less understanding of how those from socio-economically advantaged groups navigate these same institutions (but see Jacques and Wright 2015; Mohamed and Fritsvold 2010 on delinquency and the lack of policing among the privileged). ${ }^{5}$ Given that court involvement and incarceration among middle-class and white individuals has increased since the 1970s (Travis, Western and Redburn 2014) when many foundational court ethnographies were undertaken, scholarship on institutional navigation, legal consciousness, and court disparities could benefit from in-depth examinations of whether and how cultural resources and styles influence race and class inequality in the courts.

This paper undertakes such an examination by considering the cultural resource of legal expertise and the cultural styles that a diverse sample of defendants exhibits in navigating the court process. I define legal expertise in the criminal courts as knowledge about criminal law and procedure and therefore as a kind of cultural capital (see Young and Munsch 2014 on rights knowledge and rights assertion in police encounters). This definition draws on broader sociological literature on expertise among professionals in general (Barley 1996; Collins and Evans 2007) and lawyers in particular (Kritzer 1998; Sandefur 2015). In the context of civil litigation, researchers have examined how everyday people seek to use their lay legal expertise in courtrooms, in contrast to lawyers' professionalized legal expertise (see Sandefur 2015). In such civil proceedings, many litigants represent themselves pro se (i.e., on their own) or with the

\footnotetext{
${ }^{5}$ While these studies (Jacques and Wright 2015; Mohamed and Fritsvold 2010) have examined delinquency among middle and upper-middle class youth, both studies emphasize these privileged youths' evasion of (rather than engagement with) criminal justice institutions. The vast majority of respondents in both studies do not encounter (much less face arrest by) the police in their suburban communities.
} 
assistance of various kinds of non-lawyer advocates. While pro se and other non-lawyer forms of representation are rare in criminal courts (Abel 2006) where the Sixth Amendment guarantees representation by a lawyer, this paper shows that many criminal defendants nevertheless seek to acquire their own forms of lay legal expertise beyond their lawyers'. Acquiring legal expertise and seeking to use it during consequential court processing moments is, for many lessadvantaged defendants, a risk-averse response amidst skepticism of the legal system and lack of access to lawyers they trust. However, my findings reveal how reliance on self-acquired expertise often results in punitive responses from legal officials and the constraining of legal choices. These findings reveal the importance of differential navigation — or, different styles and preferences with respect to court processing - in contributing to defendants' different outcomes.

\section{RESEARCH DESIGN}

This paper draws on interview and ethnographic data collected in the Boston-area criminal court system from October 2015 to July 2017 and interview data collected in a Northeastern state-wide trial court system from December 2013 to April 2016 (see Clair and Winter 2016). The Northeastern State system is similar in many respects to the Boston-area courts. ${ }^{6}$

\section{Case}

In this study, the Boston area refers to the Boston metropolitan area of Massachusetts-an area that includes smaller cities and towns such as Cambridge, Somerville, and Quincy. The metropolitan area is racially and socio-economically diverse- and unequal. Racial disparities ${ }^{7}$ exist throughout the area's criminal justice systems. Arraignment data from 2012 indicate that for most crime types, blacks and Hispanics are overrepresented relative to their share of the general population in both municipal and superior courts in Boston and Cambridge. ${ }^{8}$ State-wide, in 2012, racial/ethnic minorities constituted 22 percent of the adult population but 33 percent of adults convicted for any crime and 38 percent of adults sentenced to incarceration for any crime. ${ }^{9}$ With respect to incarceration, the state has a higher than average black-white and Hispanic-white disparity compared to other states: in 2015, blacks in Massachusetts were incarcerated at almost eight times the rate of whites, and Hispanics were incarcerated at almost five times the rate of whites. $^{10}$

The institutional culture of the Boston-area criminal courts is structured by the Massachusetts Rules of Criminal Procedure as well as legal officials' practices and local and

\footnotetext{
${ }^{6}$ When collecting data for the earlier project in December 2013 to April 2016, my research collaborator and I promised our respondents that we would maintain the confidentiality of the state. The Northeastern State courts are similar in many ways to the Boston-area courts, as described in the next section. Throughout data analysis for this paper, I have sought to account for any differences between the two systems. Specifically, when using quotations from the Northeastern State study to illustrate a theme in the findings, I use only quotations that reflect themes also found among legal officials in the Boston-area courts.

${ }^{7}$ I do not have data on class disparities in the Boston area. Such disparities likely exist, given evidence on the existence of class disparities (often measured by employment status) in other jurisdictions.

${ }^{8} 2012$ arraignment data were provided to me from the Massachusetts Probation Services (for details, see Clair 2018).

${ }^{9}$ Statistics retrieved August 15, 2016 from the Massachusetts Sentencing Commission's document "Selected Race Statistics." URL: http://www.mass.gov/courts/docs/sentencing-commission/selected-racestatistics.pdf

${ }^{10}$ Statistics retrieved August 15, 2016 from the Massachusetts Sentencing Commission's document "Selected Race Statistics.” URL: http://www.mass.gov/courts/docs/sentencing-commission/selected-racestatistics.pdf
} 
state law regarding crime and court funding. From the perspective of most defendants, court processing involves several stages and decision-making points, including interaction with a bail magistrate at the police station, appearing in court for arraignment and bail hearings, being assessed for indigency, retaining (or refusing) counsel either through the indigent defense system or the private bar, interaction with one's lawyer pre-trial, appearing in court for myriad hearings, and managing conditions of adjudication, from fees to probation or incarceration. These processing stages are common across charge types - from misdemeanors to felonies. ${ }^{11}$ The indigent defense system is operated by the Committee for Public Counsel Services (CPCS), which consists of staff public defenders and which manages private attorneys who take courtappointed cases, also known as bar advocates. ${ }^{12}$ Defendants commonly conflate public defenders and bar advocates, given that their payment to each group - typically a $\$ 150$ fee paid to the court $^{13}$ — is the same. Seventy-six percent (37 of 49) of the defendants in my sample reported representation by a court-appointed lawyer in their most recent court case. During arraignment proceedings I observed, all defendants were provided a court-appointed attorney unless they appeared at arraignment with their own privately retained lawyer.

Several features of the indigent defense system in Boston suggest that this study's findings may provide a conservative description of institutional inequality in navigating court processing, compared to other court systems. First, in interviews with staff public defenders, they regularly recounted their low caseload in comparison to other states. In 2013, public defenders in the Massachusetts district courts had a median annual caseload of 165 cases per defender (Cruz, Borakove, and Wickman 2014). Second, defenders also have access to investigators and social workers in their offices and many noted they regularly make motions for extra funds from the court. In-house social workers facilitate clients' contact with treatment programs and navigation of other systems, including federal assistance programs such as Supplemental Security Income (SSI). Bar advocates may access some of these resources, but my interviews suggest that they do not do so as often as staff defenders. Still, they have their own resources. For instance, one private attorney who also serves as a bar advocate described how he has used "jury consultants" to conduct a "mock jury trial." Third, the pay structure of lawyers does not necessarily encourage flipping cases quickly, unlike payment schemes described in other court systems (see Eisenstein and Jacob 1977). In Massachusetts, staff defenders are salaried and bar advocates are compensated by the hour rather than the number of clients served. Along numerous other indicators, including the per capita amount of money spent on indigent defense, the Massachusetts courts offer relatively more robust representation to indigent defendants than other state court systems (see Strong 2016; Worden, Davies, and Brown 2010). Consequently, the accounts of mistrust, withdrawal, and attempts to acquire legal expertise among the defendants in my sample would likely be magnified among defendants in other court systems.

\section{Data and Methods}

\footnotetext{
${ }^{11}$ While some scholars have documented unique aspects of certain courts (see e.g., Kohler-Hausmann 2013 on misdemeanor courts), this paper focuses on processes common across court and case types in the Boston area.

${ }^{12}$ In recent years, about 25 percent of cases assigned to court-appointed lawyers are represented by staff public defenders, whereas about 75 percent are represented by bar advocates (Gurley 2014).

${ }^{13}$ Some defendants' fees are waived at arraignment, given their indigency determination. For many others who have a job or other financial resources but cannot afford to hire a privately-retained lawyer (e.g., those deemed

"marginally indigent"), these fees must be paid at adjudication. At this time, a judge can waive or reduce the fee, if a lawyer argues their client cannot afford the fee or is willing to do community service instead.
} 
Analysis centers on in-depth interviews with criminal defendants, observations among a subsample of defendants, general courthouse observations, and both in-depth and informant interviews with legal officials.

\section{Defendant Interviews}

Forty-nine criminal defendants from a range of race and class backgrounds were interviewed in the Boston area. Defendants were eligible for participation in the study if they had ever experienced court processing for a drug/alcohol-related crime, such as drug possession, drug distribution, or operating under the influence (OUI). While this inclusion criteria ensured that all defendants had experience with at least one drug/alcohol-related criminal charge, most defendants experienced other types of crimes over their life course, affording insight into a diverse range of court case experiences. In Massachusetts, sentences for convictions on drug/alcohol-related charges can range from a continuance without a finding (CWOF) to 20 years in state prison. $^{14}$

To construct a racially and socio-economically diverse sample, I relied on three recruitment strategies with the overarching aim of recruiting participants with a diverse range of experiences and access to resources (see Weiss 1994 on sampling for range). First, I identified two sampling frames of all arrested individuals in Boston and Cambridge in 2014. Unlike in prior work which often samples incarcerated populations, sampling arrestees allows for a greater range of defendants with varying levels of resources and varying court outcomes. Relying on these two sampling frames, I mailed letters to people arrested for a drug/alcohol-related crime by the Cambridge Police Department (CPD) whose home addresses were listed and who did not reside in shelters or other state institutions. I also mailed letters to a purposive sample of people arrested by the Boston Police Department (BPD) for the same offenses, seeking to sample addresses in high-income neighborhoods. In total, I sent letters to 167 homes. Forty-seven (or, 28 percent) of the letters were formally returned to me by the post office as undeliverable. Of the letters not returned, 14 individuals responded and were interviewed, resulting in a response rate of 11 percent. Second, to recruit individuals similar to those who may not have received letters due to living in institutionalized spaces or having their mail returned as undeliverable due to moving or other reasons, I shared flyers with sober houses, shelters, organizations for the formerly incarcerated, and other similar spaces. Nineteen individuals responded to this recruitment strategy. Third, to increase the chances of recruiting individuals who may be wary of talking about their criminal history, I snowball sampled by asking those I had already interviewed to share my study with an acquaintance. Sixteen individuals responded to this recruitment strategy.

These sampling strategies enabled me to construct a diverse sample of men and women from four racial/ethnic groups and with occupations ranging from investment consultant to construction worker to unemployed and educations ranging from master's degree to less than high school. Unlike research seeking to make representative claims about a population, this study's sampling design is suited for a case-based logic of analysis (Small 2009), whereby each respondent's court case is compared sequentially to their own other cases and other respondents' cases to logically assess how processes unfold similarly or differently in relation to cultural resources and styles. The goal is to reach saturation on the kinds of processes uncovered,

\footnotetext{
${ }^{14}$ According to the Massachusetts Sentencing Commission's 2015 "Felony and Misdemeanor Master Crime List."
} Retrieved August 15, 2016. Stable URL: http://www.mass.gov/courts/docs/admin/sentcomm/mastercrimelist.pdf 
providing in-depth empirical description to develop theories that may be testable in future research drawing on a representative sample (Eisenhardt 1989).

Table 1 summarizes the demographic characteristics of the sample, which includes 42 men and seven women from four racial/ethnic groups: white $(\mathrm{N}=30)$, black $(\mathrm{N}=17)$, Latino/a $(\mathrm{N}=3)$, and Native American $(\mathrm{N}=1) .{ }^{15}$ With respect to socio-economic status (SES), I define respondents by both their SES at the time of the interview and their childhood SES (i.e., parent/guardian with highest SES), given that many faced charges in middle and late adolescence. For ease of interpretation and facility in comparison to existing research in cultural sociology on institutional navigation, I grouped respondents into three SES categories - middle class (at least a four-year college degree), working class (less than a four-year college degree but maintains a fairly stable job or occupation), and poor (less than a four-year college degree and no stable job or occupation). In their childhood, 19 respondents grew up in middle-class families, 23 in working-class families, and 7 in poor families. At the time of the interview, 10 respondents were middle class, 23 were working class, and 16 were poor. Throughout the analysis, I am careful to describe how specific resources related to class and race influenced defendants' cultural styles.

\section{[Table 1 here]}

Interviews began with a short demographic and attitudinal survey. Upon completing the survey, respondents were asked about their personal background, including their childhood experiences, past jobs, and their daily life. Respondents were next asked to choose at least one court experience that they would like to discuss in detail—-from arrest/summons through to final adjudication. In total, the 49 respondents discussed 132 court case experiences, with a median of 2 cases per person, thereby affording insight into how changes in access to resources influences different styles of engagement within the same person. Cases ranged from shoplifting to drug possession to armed robbery. Slightly more than half of the cases were drug or alcohol related. With respect to each case, respondents were asked details about their arrest, detainment pre-trial, engaging with their lawyer, attending court dates, managing pre-trial probation, choosing to go to trial versus take a plea, and managing their formal legal punishments.

\section{Observations and Legal Official Interviews}

In addition to the defendant interviews, I rely on various other forms of data. First, I draw on observations of court proceedings among six interviewed defendants who allowed me to observe their open court dates. Table 2 summarizes the demographic characteristics and legal experiences of these six respondents. Second, I draw on over 100 hours of general courthouse observations conducted mostly in two courthouses in Boston - a municipal court and the Suffolk County Superior Court. Third, I draw on interviews with two samples of legal officials. The first sample is of 35 legal officials practicing in the Boston-area courts. These data consist of informant interviews with 1 judge, 3 prosecutors, 7 bar advocates, 1 public defender, 9 probation officers, 8 police officers, and 6 other officials, including social workers and clinical staff at sober houses. Informant interviews focused on confirming processes identified in interviews and observations among defendants. The second sample is of 110 legal officials practicing in a Northeastern state

\footnotetext{
15 These numbers add up to more than 49 because a few respondents identified as more than one race/ethnicity, as
} indicated in Table 1. 
trial court system similar to the Boston-area court system. The sample includes 59 judges, 24 prosecutors, and 27 public defenders. In-depth, semi-structured interviews with these officials asked about their professional decision-making at various stages of court processing and their beliefs about defendants.

[Table 2 here]

\section{Analysis}

Coding categories emerged inductively and iteratively throughout data collection (Glaser and Strauss 1967). In final rounds of coding, I focused on themes related to cultural resources (in particular, legal expertise and its acquisition by defendants) and cultural styles (in particular, when and with what consequences defendants either delegated authority to lawyers and relied on lawyers' expertise or withdrew from lawyers and relied on their own legal expertise). I analyzed interactive moments between lawyers and clients in each court case, as described in interviews and observed in real time. This approach enabled in-depth comparison of similar and different interactive moments not only between defendants but also within the same defendant, whose cultural style and access to resources can vary from case to case and interaction to interaction (see Small 2009 and Tavory and Timmermans 2013 on cross-case comparisons). In-depth analysis of moments and cases also allowed for a careful assessment of how the cultural styles of delegation or withdrawal unfolded in each court case's "visualizable sequence of events" (Weiss 1994, p. 179). Such an analytic approach cannot make counterfactual causal claims about the precise effect of any one variable in explaining defendants' legal outcomes; rather, this approach is uniquely suited to providing on-the-ground evidence of the cultural and social processes that shape observed inequalities (Small 2009).

\section{FINDINGS}

I begin with an in-depth examination of two respondents' experiences with their most recent court cases, as observed in real time and described in their interviews. Arnold (B, WC, MC) ${ }^{16}$ is a college-educated black man facing a gun possession charge, and Tonya (W/N, P, P) is a poor white and Native American woman facing a probation violation for using cocaine. Whereas Arnold experiences relatively successful navigation of the courts when delegating authority to his privately retained lawyer, Tonya experiences frustration, withdraws from her court-appointed lawyer, and experiences prolonged entanglement with the legal system.

When I interviewed Arnold (B, WC, MC), he was dealing with a gun possession case. A Boston native, Arnold attended a university in the southeastern U.S., where he played college basketball. After college, he returned to Boston to continue training for a professional basketball career. He had just been drafted to a minor league team when I met him. An outgoing young man, Arnold often travelled to New York to visit friends. On his way back home from one of

\footnotetext{
${ }^{16}$ All names are pseudonyms (often chosen by the respondent), unless the respondent asked for me to use their real name. I designate each respondent by their race $(\mathrm{W}=$ white, $\mathrm{B}=$ black, $\mathrm{L}=$ Latino/a, $\mathrm{N}=\mathrm{Native}$ American) and social class $(\mathrm{MC}=$ middle class, $\mathrm{WC}=$ working class, $\mathrm{P}=$ poor $)$ throughout the text. The first listed class status designation denotes childhood class status, whereas the second listed class status designation denotes current class status at the time of the interview. For example, a person designated as (W, MC, WC) is white, comes from a middle-class childhood, and was working class at the time of the interview.
} 
these trips, he and a couple friends were pulled over by a state trooper in a rural, majority-white county in western Massachusetts. The trooper alleged that the car, which Arnold had borrowed from a friend, had been reported stolen. Upon searching the vehicle, the trooper found an unregistered gun. The passengers were all arrested, but none of their fingerprints were ever found on the weapon.

Arnold was first assigned a court-appointed attorney, whom he did not trust. In the interview, he recounted various reasons for mistrusting the lawyer. He recalled she was not effective in the courtroom: "She's a kind woman $[\ldots]$ and worked diligently to put together a case for me [but ...] she had a strong [Eastern European] accent and so I think they [other court officials] couldn't understand her." She also did not fully believe in his innocence, telling him that he should be prepared to "have canteen money ready" for jail. To Arnold, this suggestion was "a red flag for me that she was willing to accept what the courts wanted to do, rather than forcefully impose her will on the situation on my behalf." Skeptical of his lawyer's skills as well as her willingness to use them on his behalf, he worked with his basketball agent to find another attorney - a white male lawyer without an accent who was also a former basketball player. Arnold's family helped him pay his attorney fees. And over the course of Arnold's case, he and his lawyer regularly bonded over their shared experiences with collegiate athletics.

Later, I followed Arnold to court the day his case was set for trial. In the interview, Arnold told me that he and his lawyer had originally planned for a jury trial. However, on the morning of trial, Arnold's attorney suggested that it may make more sense to do a jury-waived trial, in which the judge (who his attorney told him was a former defense attorney) would rule on his guilt. I watched quietly as Arnold thought for a second, then looked to his lawyer and asked, "What do you think I should do?" His lawyer explained the difference between the two types of trials and the benefit of going jury-waived, noting that the jury in the county would likely be allwhite and therefore may not look objectively at the lack of evidence against him. He suggested going jury-waived might be the best option. Without hesitation, Arnold said, “OK, let's do it. I trust you." His trust allowed him to delegate authority to his lawyer's expertise, relying on his lawyer's knowledge of the judge, the courthouse culture, and how the particulars of his case could be misunderstood by white jurors. That afternoon, I watched as Arnold would be found not guilty.

Tonya (W/N, P, P), who has struggled with substance use disorders since childhood, recounts a very different experience with her lawyer. When I interviewed her, she was facing a probation revocation hearing for using cocaine. During our interview, she told me that her courtappointed lawyer - one of many "public pretenders" she has had represent her over her lifetime - was a nice enough woman but that she generally does not trust court-appointed attorneys, because "they're all buddies with the district attorneys" and "work for the courts."

A month after the interview, I followed Tonya to court for a hearing. Before the hearing as we waited for her lawyer, Tonya complained that her lawyer was always late, and "she never has time to visit me during my probation meetings." Tonya told me about how she was working to help herself. She had been speaking to the women in her sober house about how she could get a letter from a psychologist who studies the brains of people with addictions; she planned to acquire the letter to show at her next court date. When her lawyer arrived, Tonya asked for advice about how to issue a complaint about her sober house's living conditions, which she complained was full of mice. "Is there someone I can call?" she asked. Her attorney told her that she was not sure but emphasized to her that, above all else, she must stay in the sober house as mandated by probation. Outside the courthouse, Tonya lit a cigarette and sighed, visibly 
frustrated by her attorney's insistence on "following the rules" no matter the cost to her personal life as well as her attorney's lack of knowledge about how to issue a complaint about her sober house.

Tonya's mistrust and frustration resulted in her often withdrawing and declining the expertise of her attorney. To begin with, one of the counts of her probation violation hearing included the fact that she violated her probation officer's mandate - and her lawyer's insistence - that she remain in the sober house she was assigned to by the court; instead, she violated the rules of the sober house and was forced to find another sober house on her own. In the court setting, Tonya also declined her lawyer's advice. Just before the final violation hearing, she told her attorney that she wanted a chance to tell the judge her version of events - to explain that she only used cocaine in violation of her probation because she was homeless, was almost raped, and had nowhere to sleep but at a friend's house, who also used the drug and to explain that she left the sober house she was originally assigned to by probation not because she broke any rules but instead because the house was "unstable and chaotic." Tonya's attorney cautioned against this strategy, telling her that the judge "doesn't want excuses;" he only cares about whether "you play by the rules [...and] take responsibility." At the final hearing, her probation officer recommended to the court an extension of her probation with no jail time, and Tonya was asked if she had anything to say to the court before the judge ruled. Tonya began to speak and, at one point, ignored her lawyer's advice by explaining the reasons for her relapse and criticizing the living conditions of her former and current sober houses. But it appeared to me that the judge - sitting on the bench above her with his raised eyebrows and pursed lips - was dubious of her account. Tonya may have also sensed this and quickly changed her tune, telling the court: "I'm trying to learn and be responsible, your honor. And also, I want to apologize [to the court] ... I'm doing the best I can." Ultimately, the judge followed probation's recommendation, reinstating her probation without jail time. She would be mandated to remain on probation for two more years, at the least. And the judge warned her: "undergirding all of this is you wanting to do things your way. I don't want to find out weeks from now that you violated again [...because] you want to do things on your own terms."

Many elements of Arnold and Tonya's cases are distinct and have been shown to influence formal legal outcomes - e.g., the severity of their charges, their factual guilt/innocence, their history of involvement with the court, their race/ethnicities, and their genders; yet, comparing their unique cases underscores the common factor of mistrust in shaping cultural styles alongside these important case differences. For both Arnold and Tonya, mistrust of their lawyers constituted a skepticism of their lawyers' incentives and their lawyers' commitments to their personal goals, including goals with respect to court strategy, sentencing options, and dealing with poor housing despite probation conditions. Mistrust resulted in withdrawal for both at times, whereas for Arnold (who was able to leverage social and economic resources to retain a new lawyer) trust of his second lawyer resulted in delegation of authority and relative ease of court navigation. I revisit their experiences throughout the findings, incorporating evidence from other respondents' case experiences and from the accounts of legal officials.

\section{Delegation versus Withdrawal}

Existing scholarship has documented mistrust of lawyers among defendants (Boccaccini and Brodsky 2001; Boccaccini et al. 2004; Casper 1972), especially those who are poor and/or racial/ethnic minorities (Clair 2018). Much of this mistrust is rooted in structural realities such as 
a lack of access to social and economic resources that enable defendants to opt out of the indigent defense system (Clair 2018), as well as defendants' perception that court-appointed attorneys have misaligned incentives (Wilkerson 1972) or that some lawyers do not allow their clients to participate in their own legal defense (Boccaccini et al. 2004).

In this section, I describe the implications of trust and mistrust for defendants' cultural styles of engagement during court processing. Across various domains, trust has been shown to facilitate positive micro-level interactions (Cook 2005; Levine 2013; Smith 2010). Among defendants in my sample, I find that those who trust their lawyers delegate authority and rely on lawyers' legal expertise, whereas those who mistrust their lawyers withdraw from them and seek to acquire their own legal expertise. The style of withdrawal and accrual of one's own legal expertise is commonly experienced when defendants in my sample find themselves in situations of social and economic disadvantage. These cultural styles constitute two main components of differential navigation.

\section{Trust, Delegation, and Reliance on Lawyers' Legal Expertise}

When defendants in my sample trust their lawyers, they often delegate authority to them and rely on their lawyers' legal expertise, contributing to a relative ease of navigation (though no respondent's experience with the courts was without stress or uncertainty). Arnold's (B, WC, MC) experience described earlier illustrates the process of delegation and reliance on lawyers' expertise. Arnold's trust in his second lawyer enabled him to delegate to his lawyer's expertise in at least two important decision-making moments. First, during our interview, Arnold was willing to take his case to a jury trial because his lawyer suggested that the evidence against him was weak and that he was confident he could win at a trial. Second, during my observation of him on the day of trial, I watched how he immediately relied on his lawyer's expertise with respect to the benefits of doing a jury-waived (or, bench) trial instead, in which a judge rather than a jury would rule on his guilt. Ultimately, Arnold's faith in his lawyer and his willingness to allow him to use his expertise to assist in his legal defense paid off; he was found not guilty.

Some defendants recounted trusting and delegating authority to their lawyers because of their naivete about the court system. This process is most common when defendants have had little contact with the legal system, sometimes due to their youth, their living in middle-class communities, or both. For example, Kema (W, MC, MC), who was raised in an affluent family in California, recounted the complete weightlessness of her first arrest experience. A high school student in the 1980s, she crashed her car into a picket fence on her way home from a party. She was arrested for driving under the influence. Her father hired a neighbor to represent her and, as she recalls, the case simply disappeared. Kema told me: "I never went to court or anything." She recalled fully delegating authority to her lawyer and her father, both of whom "took care of everything [...and] just took the reins." Kema did not face any formal legal consequences for her crime and, to this day, is unaware of how her lawyer resolved the case.

Kema's story reflects a boarder pattern regarding delegation to lawyers among the individuals I interviewed: they are more likely to recount delegating authority in their earlier court experiences than later in life. Delegation earlier in life reflects the role of parents as a social resource as well as the way mistrust and acquisition of legal expertise slowly grow more intense with repeated experiences of policing and court involvement, often associated with living in racially-segregated, low-income neighborhoods in the Boston area (see Clair 2018; Fagan et al. 2015). When Joseph (B, MC, WC) was arrested at 16 for breaking and entering, he was more 
worried about his mother's punishment than the legal system's: “"My mom's gonna kill me, man!' I'm not worrying about the cops." His engagement with his lawyer was mediated through his mother. After his mother and his lawyer "worked something out," he was sentenced to probation (which he served at the Boys and Girls club), and his mother had to pay restitution.

Similarly, Christopher (W, MC, P) recounts that during his first arrest at 16 for assault and battery with a deadly weapon, he "was trusting [of]" and delegated authority to his courtappointed attorney given his naivete: "I didn't even know what the law was at that point." He ultimately received a CWOF with six months to a year of administrative probation. Meanwhile, from his aunt and uncle (who were his guardians), Christopher recalled that he "got the business from them, you know. Punishment, the whole nine yards." Years later at the age of 33, however, Christopher was arrested for possession of marijuana with intent to distribute. He was again assigned a court-appointed attorney, but this time he was wary. He had come to understand how the structural position of public defenders makes it difficult for them to devote time to their clients: "I don't doubt she [public defender] worked hard for me [... but] she seemed flakey to me. I know public defenders have like huge caseloads and no time [...] I mean, a private attorney - if you get them - they're going to court for you that day. That's it. Public defenders could have like 10 other people up there that they're doing cases with that day."

Trust and delegation of authority to lawyers also depends on how lawyers are obtained; when defendants find lawyers through trusted social ties or trusted institutions, they are more likely to delegate. When Ryan (W, MC, MC) was a sophomore in college, he was arrested for an OUI. His father contacted a friend, who was a detective, for advice on finding a lawyer. The detective helped him find an attorney, whom Ryan recounts trusting in part because the attorney also happened to be the son of the county's DA. Ryan's trust in his lawyer also emerged from his lack of experience with the law: "I was so naive to the whole criminal justice [process] and how it works. [...] I wasn't brought up that way, and I'd never seen myself in that situation." Ryan's lawyer's familiarity with the system, by contrast, indicated to Ryan he was trustworthy: "Yeah, he [my attorney] was good [...] it was reassuring in the sense he seemed like it was a routine thing, he wasn't worried about it. While I was scared shitless." Like Ryan, Amanda (W, MC, WC) also faced her first charge while in college. She hired a lawyer through an organization that supports marijuana legalization - an organization that she had regularly referenced online when she and her boyfriend were buying and selling marijuana across state lines. The lawyer's affiliation with the organization as well as his ability to "put [the court process] in layman's terms" was important in her decision to delegate authority to him. She recounted receiving a sentence of one year probation and five months of community service, attributing her sentence to her lawyer: "I believe [...] it is my lawyer that helped me get the sentence that I got."

In sum, access to economic resources assists in hiring lawyers in whom defendants are willing to trust. Moreover, parents and other authoritative social ties assist in finding — and mediating defendants' relationships with-lawyers. In addition, defendants who live in middleclass neighborhoods and communities exhibit a naivete with respect to the law that contributes to a willingness to trust in legal officials, such as lawyers. Finally, in many of the cases described in this section, defendants recounted experiencing a surprising ease in their court interactions. While court outcomes have been shown to depend on numerous variables such as nature of the offense, defendant's criminal history, and the biases of legal officials, delegation of authority to lawyers within a trusting interactive relationship may also play a role in mitigating punishment.

\section{Mistrust, Withdrawal, and Acquisition of Defendants' Legal Expertise}


Withdrawal from lawyers, declining lawyers' expertise, and attempting to acquire legal expertise on one's own are processes that often occur amidst mistrust. Tonya's (W/N, P, P) experience described earlier is illustrative. In several moments, Tonya withdrew from her lawyer and sought to put her own acquired expertise to use. Her attempt to procure a letter from a psychologist (which she was ultimately unable to do) was one strategy her lawyer never affirmed would help. During her final hearing, when the judge asked if she wanted to speak, she attempted to set the record straight on her own terms, providing justifications for violating probation, rather than heeding her lawyer's suggestion to simply admit fault and defer to the judge. Sensing her approach was not working, she ultimately followed her attorney's advice and was sentenced to a continued period of probation, with a stern warning from the judge.

Less-advantaged defendants in my sample, especially those who are unable to opt out of the indigent defense system, often recount mistrusting their lawyers while at the same time recognizing that some lawyers can be good advocates. Court-appointed lawyers in particular are understood to be in a precarious professional position, given that their salaries are paid by the state. Recall Tonya's (W/N, P, P) description of public defenders as "work[ing] for the courts." Court-appointed lawyers are also described as overworked. Recall Christopher's (W, MC, P) description of one of his public defenders as "flakey" and burdened by a "huge caseload." Sometimes, less-advantaged defendants in my sample recognize that not all lawyers-even court-appointed ones - are untrustworthy. Tweedy Bird (B, WC, WC), for example, expressed a general distrust of lawyers, but felt that sometimes you can happen upon a quality lawyer through the indigent defense system: "You go for a court-appointed lawyer and you don't know who you're going to get [...] I've had the same lawyer as [a Boston-area celebrity ...] I've had some powerhouses." Scott (W, WC, P) told me: "Don't get me wrong, there are some good court-appointed attorneys because they have to rotate, but there are lousy lawyers too." Overall, individuals in my sample acknowledge that there are some lawyers who are more competent than others, both within and outside the indigent defense system.

Indeed, mistrust and skepticism of court-appointed lawyers often has less to do with a lack of faith in their competence and more to do with a lack of faith in their willingness to use their legal expertise on their clients' behalf. Several individuals in my sample suspected that lawyers reserve their most ardent advocacy for clients who pay them for their services. For instance, reflecting on the difference between paying for a lawyer and being assigned one by the court, Justin (W, WC, P) said: "When you got a court-appointed lawyer, nothing goes in your favor. I view it as the more money that is pumped into the system it makes them happy, you know?" And when I asked Jane (W, MC, MC) whether she thought retaining a private attorney was necessary, she told me: "Well, it's necessary if you want [...] to feel taken care of." Even staff public defenders (who never retain clients privately) are sometimes believed to be negatively influenced by money — or its lack thereof. For instance, Royale (B, WC, WC) told me that public defenders have no monetary incentive to pursue all legal avenues on their client's behalf: "He's not getting paid enough, and half the time the public defenders are working with the DA. So they try to get you to take deals." Royale's comment reflects his awareness not only of defenders' low salary but also of their need to maintain standing and credibility in relation to district attorneys, with whom they must maintain professional working relationships (see Eisenstein and Jacob 1977 on the courtroom workgroup).

Lack of faith that lawyers will use their expertise on one's behalf often results in withdrawal and attempts to acquire one's own legal expertise. Tonya's (W/N, P, P) mistrust 
resulted in several attempts to accrue her own expertise. Some defendants generalize prior negative experiences with lawyers to inform their mistrust of and withdrawal from future attorney-client interactions. Accruing one's own expertise becomes a way to prepare for future legal entanglements. For instance, Jeffrey (B, WC, P) described his growing mistrust and frustration after his first court experience, when he was arrested and later convicted on a cocaine charge. He told me:

The lawyers told me they would get me off and they never got me off. And ever since then, that's what I've been dealing with. Because I don't have money [for] paying lawyers $[\ldots]$ It's very messed up the way they take a case but they don't want [...] to represent you the way they're supposed to and then when you ask for a new lawyer you can't even get any lawyers. If you're going to jail because of all these charges and he's not representing you-I mean I know a lot of people who know about the law more than the other people and [than] their lawyers! Um...that's one thing about jail, especially [facility name redacted], they have a law library where you can look over your case. You can do a lot with that. You know a lot of people have overturned their case by getting into the law library.

After time in prison, Jeffrey's mistrust of lawyers worsened through conversations with other inmates. Consequently, he recalls how he and other incarcerated individuals began to accrue and rely on their own legal expertise. As he insists, "I know a lot of people who know about the law more [...than] their lawyers!"

Defendants' legal expertise is acquired through social ties on the street, in their families, or in jail and through their own courthouse observations. Jail or prison often provide formal opportunities for defendants to acquire such expertise. State prisons in Massachusetts provide access to library services, which includes access to legal materials. ${ }^{17} \mathrm{Ken}$ (W, WC, WC) told me that he accessed library services and decided to take "constitutional law" in prison after several arrests. He recalled:

I took constitutional law-I like the law. You know when you're incarcerated, you know, some guys do and I think everybody should get to that law library and look at your case and learn about - if you're going to commit a crime you want to learn how not to be caught. It's like if you're going to be a mechanic, you need to study some car manuals I'd imagine.

Incarceration also presents individuals with informal opportunities to share legal expertise with others seeking advice. Ken shared his acquired expertise with another incarcerated person: "[I] helped another kid get $\$ 100,000$ back that his mother put up and he violated um...the conditions of his bail so...the city prosecutor's office was trying to seize the bail money and they did seize it. And I filed a motion.”

\footnotetext{
${ }^{17}$ According to the Massachusetts Department of Correction's (DOC) regulations, these materials are to be provided to "every inmate." The Massachusetts DOC writes: "Every Inmate shall have access to legal materials. As suggested by federal and state court rulings and national standards, legal materials should include at a minimum: state and federal constitutions, state statutes, state decisions, procedural rules and decisions and related commentaries, federal case law, court rules, practice treatises, citators, and legal periodicals." This statement was retrieved on February 5 , 2018 under file number "103 CMR 478: Library services" and regulatory authority "MGL c. 124, § 1(c) and (q)." Retrieved at: https://www.mass.gov/files/documents/2017/09/04/103cmr478.pdf
} 
Absent experiences of incarceration, some defendants accrue legal expertise through social ties in their communities as well as their own personal observations of court processing. Caleb (B, MC, MC) learned about court procedure through his personal observations. He told me: "The first time I was in [the courthouse], I went back a couple of days later just to see how it worked. I sat there for like six hours. Just watching people go through." Caleb explained to me that, given his wariness of his court-appointed attorney and his general distrust of the legal system ("being black you sort of have this fear of the police [...everyone] around me were also terrified of police"), he was trying to understand the court process for himself:

I just wanted to see how it worked because when I was there they just - this was the first time um they gave me a lawyer. And then I got there, and he gave me a card and was like, "Call me," [and] walked away. And I was like: "That's it? I have a lot of things to tell you. Wait, wait." [...]

When I asked Troy (W, P, P) - a young man who spent his childhood skipping school and "hanging out with the wrong crowd"-about his knowledge of criminal procedure, he told me: "I've had friends who have been in the system for a long time. And like I said, I know a lot of cops, you know what I mean?" Earlier in the interview, Troy remarked that he "grew up [around] a lot of cops."

In sum, less-advantaged defendants have reason to mistrust lawyers and the court process more broadly, often resulting in withdrawal from lawyers and accrual of their own legal expertise.

\section{Costs of Withdrawal and Self-Acquired Legal Expertise}

In this section, I describe the costs of withdrawal from lawyers and of reliance on self-acquired legal expertise. In the first part, I reveal the punitive experiences recounted by defendants when declining the expertise of their lawyers and relying on their own, triangulating defendants' accounts with interview data from lawyers and observational data of legal officials' punitive reactions. In the second part, I show how less-advantaged defendants' self-acquired legal expertise about the reality of sentencing alternatives in their daily lives can constrain their legal choices, resulting in them sometimes preferring to choose what legal officials and social scientists often view to be harsher court processing outcomes.

\section{Defendants' Negative Experiences and Legal Officials’ Punitive Reactions}

Defendants who withdraw from their lawyers often recount experiencing negative legal outcomes. For instance, Scott (W, WC, P), who suffers from mental illness and was charged with threatening to intimidate a witness, recalls feeling stigmatized by his lawyer and thus withdrawing from him. He told me: "Yeah, [I am] mentally ill, and they [the lawyer] knew that. They never knew my whole childhood." Scott recalls that he "just spoke a couple of times" with his lawyer. In retrospect in the interview, he reflects that a better attorney-client relationship may have benefited him because the court would have been able to learn about the extent of his mental illness and treated it as a mitigating factor: "Maybe that would be something that would make it easy on me." Scott ultimately pleaded to 18 months in jail. Confirming Scott's perspective, a public defender told me that information about a client's illness can play favorably 
at sentencing. When asked how she crafts sentencing recommendations, this lawyer said: "If your client has a drug problem and [...] has attended an AA meeting three times a week and [...] got themselves into a month-long program and also has a part-time job now, you know, you have all that material to work with. It's really what you do with it."

When defendants attempt to rely on their own self-acquired legal expertise, they are often penalized by the court for asserting due process rights at inappropriate times or in inappropriate ways. Tonya's (W/N, P, P) experiences illustrate this point. Despite her lawyer's warnings, she attempted to share the mitigating circumstances of her drug use during her probation revocation hearing. She was technically correct in her knowledge that judges often consider mitigating factors, such as histories of substance use addiction or lack of housing (Clair and Winter 2016). Yet, the judge did not want her to share mitigating factors at that moment; instead, as Tonya's lawyer insisted, he wanted to hear her accept fault and exhibit a willingness to change - a degrading form of behavioral social control that scholars have documented across various criminal justice settings (Braithwaite 1989; Harris 2009; Kohler-Hausmann 2013; Van Cleve 2016).

In general, defendants' attempts to speak in open court are common instances in which defendants' uses of their legal knowledge outside of the mediation of their lawyer is devalued by the court. For instance, in a municipal courthouse in Boston, I observed a black man, dressed in a jersey and baggy jeans, become upset during his pre-trial hearing. His attorney asked the judge for a motion to suppress hearing with respect to the potential presentation of video footage of his arrest. The prosecutor argued that the video footage should be included because it showed the defendant resisting arrest. At this suggestion, the defendant suddenly shouted, "Man, I'm only one person. I can't fight four officers!" His outburst was an attempt to articulate how his actions did not meet the legal definition of resisting arrest. His attorney tried to quiet him, but he rebuffed his attorney's subtle reproach, frustrated by the prosecutor's suggestion. The judgevisibly annoyed and having yet to hear full arguments from opposing counsel-calmly said, through pursed lips, "Please speak through your attorney, sir." Although I was unable witness whether the motion was successful, the judge appeared to view the defendant's speaking without his lawyer's mediation unfavorably.

Relatedly, in interviews with lawyers, they often emphasized that even though their clients technically have certain rights, they rarely advise their clients to speak out or draw attention to themselves in court. In part, this strategy is to protect a client from incrimination (see Natapoff 2005); but also, this advice reflects the court's devaluation of defendants' expertise. For instance, during jury selection, clients have a right to participate in the "examination" of potential jurors. Yet, public defenders often advise their clients that they take a back seat. When asked if he involves his clients in jury selection, a public defender remarked that "I prefer that they don't" come up to sidebar next to potential jurors because "I've seen — physically seensome jurors look [uncomfortable] and like move away." Another public defender from the Northeast State study said: "they have a right to [but...] it's very logistically complicated. Like there's a lot of pieces of paper and there's a lot of, you know. The way it works, it's really hard to involve the client." In addition, some defense attorneys also articulated their hesitation to have their clients - especially those with low levels of education - take the witness stand at trial (see Emmelman 1994). One public defender said, "a lot of the time you don't want your client on the stand - not because they're hiding something but because they don't need to take the stand, they might not be articulate, they could be confused by a question, they can say something they regret 
later. You don't want to put a young person with a limited education —or even with an education - up against a prosecutor."

On a more emotional level, lawyers sometimes describe having less investment in, or even having anger toward, clients who question their professional authority and seek to acquire their own expertise. Lawyers in my sample often recall "uncooperative" or "difficult" clients. One public defender confided that "[C]lients are always looking for a reason as to why they shouldn't trust you." Another lawyer, a bar advocate, told me that she grows frustrated when defendants attempt to use their own knowledge of criminal law without her assistance. For instance, she described a time when one of her clients attempted to file a motion without her knowledge while he was detained pre-trial. He submitted the motion directly to the judge without informing the prosecution. According to this lawyer, motions must be submitted to a judge in the presence of a representative from the DA's office - otherwise, it constitutes ex-parte communication, which violates criminal procedure. When this happens, the court clerk will notify the defendant's lawyer that the defendant is trying to file a pro se motion. The lawyer recalled to me that it "really pisses me off" when defendants seek to file motions on their own because it calls into question her "legal expertise and practice of the law."

Some defendants decline lawyers' expertise in favor of their own when they feel they have nothing to lose, given their perception that their lawyer will not assist them in exercising certain rights. Defendants often described frustration at their lawyers' refusal to file motions to dismiss charges or suppress evidence, given their self-acquired expertise of such procedural strategies. For instance, Kevin (W, WC, WC) told me:

I'm telling [my lawyer] to file these motions because I'm looking up stuff on my own and asking questions of other people. So, I'm like, "File this, this, and this." And he's like, "Nah, the judge is a bitch. She won't do it. It's not gonna work."

Some respondents accept their lawyers' refusal, but others do not. Gregory's (B/L, P, P) experience of filing a motion from jail against his lawyer's advice is illustrative. After being arrested for selling cocaine in the South End of Boston to an undercover police officer, he was assigned a court appointed attorney whom he recounts immediately stereotyped him as "the type of person who won't stop selling drugs." He began to withdraw from his attorney after their first meeting: "I knew right then and there it [the attorney-client relationship] was going down the wrong road." While in jail pre-trial, he went into the "law library" and talked to "people who know the law more than you, and they sit down with you or you pay them." With the help of fellow detainees, he filed a motion to suppress the evidence relating to the exchange of cocaine with the police officer. But, the judge denied the motion: "In the court, you mail it. You put it, and they look at it. And then [...] nine times out of ten they're going to deny because the judge, you know, he's an asshole."

Whereas withdrawal from lawyers and defendants' use of expertise is punished or simply ignored, delegation to lawyers and deference to the court's definitions is rewarded. Don's (B, $\mathrm{MC}, \mathrm{WC}$ ) experience pleading guilty reveals how court procedures and the reactions of legal officials subtly coerce defendants into deferring to their lawyers and accepting the court's definition of their crimes. After our interview, I watched Don-hunched over, solemn, and wearing a gray hoodie and sneakers - plead guilty to several charges relating to his arrest for possessing and distributing drugs. As the clerk read each count, there was a palpable silence in the courtroom when Don hesitated to answer "guilty" to one of the charges. When he finally 
muttered, "guilty," both the clerk's and the judge's faces relaxed. Later, after the prosecutor spent about seven minutes reading the facts of his case (many of which Don had contested in the interview), the judge asked him:

Judge: Do you dispute any of these things?

Don: No.

Judge: Are the facts told to the court true?

Don [hesitates, then mumbles]: Yes.

Don was ultimately sentenced to two years in state prison and three years of probation for several drug offenses. In his final words to the court, he said:

I know I'm better than this, but I am also a drug addict. The opioid epidemic is real. I've been going to get help at meetings for years now. And I feel I need that more than anything else-I need help. I apologize to the court for my actions.

The judge responded: "Well, you've got the right attitude. You will continue treatment after these two years, and I know you will continue down the right path." While Don's ultimate compliance resulted in a lesser sentence than he otherwise would have received (several of his charges were dropped in exchange for his plea), his compliance still could not save him from prison.

The decision to draw out a plea deal against the perceived pressure of one's lawyer is one instance in which not fully delegating authority to a lawyer can, at times, prove advantageous for defendants' formal legal outcomes. But in this situation, defendants are not so much declining the expertise of their lawyer as much as they are momentarily resisting the perceived pressure to plead too quickly. Indeed, waiting things out and insisting one's attorney ask for multiple continuances and multiple negotiations in order to extract a lesser final plea deal often requires an efficacious and trusting working relationship with one's lawyer. For instance, Don (B, MC, WC) described to me how he had a positive relationship with his court-appointed lawyer, whom he trusted and with whom he worked for more than a year to secure a deal he was comfortable accepting. Don's mother-in-law, a retired detective, had helped him confirm that the lawyer was "good;" as Don recalls, "She called some people and asked about him, and they said he was one of the best, so that's why we stuck with him." During Don's plea hearing, his lawyer even stated to the court: "Don has been a wonderful client, and he's been working to get clean for the over two years that I've known him."

For a number of defendants, the extended negotiations and continuances required to draw out a less punitive plea deal comes with its own processing costs (see Feeley 1992 [1979]). For example, Troy (W, P, P) recounted to me how he initially refused his attorney's suggestion that he plead guilty to one year of probation for his first drug possession charge. He felt he should be able to get a better deal given his clean record:

Like, he was coming back to me like "Yeah, just plead guilty and take a year probation and do this right now." No, I'm not doing it. You know what I mean? Because at this point I didn't have a record. And usually the first couple of times they're easy on youlike, they'll work with you. So I said to him, “This is my first arrest. I'm not taking a year probation. For what?" 
While waiting for a better deal, Troy was not detained pre-trial but was nevertheless mandated by the court to complete detox programs - a "performance-conditioned" form of leniency that allowed the court to monitor his behavior (Kohler-Hausmann 2013). Several months later, after not showing up to court and being re-arrested on default warrants, Troy learned that his attorney had finally negotiated a CWOF with terms of probation. He took this deal. It was a marginally better outcome than immediately pleading guilty with terms of probation because it would not leave a conviction on his record if he abided by the terms of his probation for a certain period of time. Troy's experience reveals the formal sentencing benefits of waiting out a plea for some defendants, as well as the informal costs of pre-trial conditions and the risks of re-arrest.

In sum, defendants' efforts to use their self-acquired expertise is often punished by their lawyers as well as the institutional rules of the court process. Delegation of authority and deference to the court enables relatively less punitive court experiences.

\section{When Defendants' Expertise Constrains Legal Choices}

Defendants' self-acquired legal expertise constitutes not only knowledge about criminal procedures but also experiential knowledge about how the criminal law and techniques of legal control operate in the daily lives of people like them (see Stuart, Armenta, and Osborne 2015). Expertise about the everyday realities of certain sentencing options can constrain defendants' court processing choices and contribute to preferences for seemingly-harsher formal legal outcomes. In my sample, this process is most often described in the accounts of defendants living in, or with social ties to, highly-surveilled, poor neighborhoods of color in the Boston area. Among these less-advantaged defendants, the realities of police and court surveillance constrain their abilities to take advantage of less-punitive sentencing alternatives.

Less-advantaged defendants' expertise regarding the everyday realities of their social positions in their neighborhoods and communities influences their understandings of legal choices at sentencing. Their understandings can be at odds with those of legal officials crafting laws, policies, and everyday adjudicative decisions regarding the purposes of various sentencing options. In my sample, this disjuncture is especially evident with respect to the logic behind graduated sentencing schemes, such as intermediate punishments. Morris and Tonry (1991, p. 4) define intermediate punishments as sentences between administrative probation and incarceration, such as "intensive probation, substantial fines, community service orders, residential controls, [and] treatment orders." Such sentences are commonly referred to as alternative sanctions because they are often offered as ostensibly less-punitive alternatives to incarceration. However, the ordering of sentencing options has been shown to be subjective (see Petersilia 1990; Wood and May 2003). ${ }^{18}$ Among the defendants in my sample, I find that what is considered a better or worse legal choice of a sentence depends on defendants' expertise about

\footnotetext{
${ }^{18}$ Among samples of convicted offenders and/or incarcerated individuals, scholars have found that certain intermediate punishments were perceived as harsher than certain periods of incarceration (see Martin, Hanrahan, and Bowers 2009; Petersilia and Deschenes 1994; Spelman 1995). Some scholars have considered whether preferences vary by race/ethnicity. For example, Wood and May (2003) find that, on average, about a quarter of black probationers in their sample reported that they would rather serve time in prison than various alternatives. However, I am unaware of research that has considered class differences or considered how such preferences constrain defendants' legal decision-making.
} 
their neighborhood and community social ties and access to resources that would enable their effective compliance with alternatives to incarceration.

Whereas the legal preferences of socio-economically advantaged defendants in my sample often align with lawyers' and policymakers' assumptions about what constitutes a better or worse sentence, the legal preferences of less-advantaged defendants (especially those living in poor neighborhoods) often do not. Several working-class and poor black defendants in my sample recounted preferring sentences of incarceration over sentences of probation. For instance, William (B, WC, MC), who was on probation after his first conviction, told me: "probation is not for black people." He elaborated:

Author: What was being on probation like?

William: It's...probation is not...Probation is not for black people.

Author: Hmm. What do you mean by that?

William: You're treated differently on probation-African Americans are treated totally different on probation than white people are treated on probation, than anyone else is treated on probation. And that goes for Asians, Hispanics, you name it, whatever nationality is. My personal experience and other people I've talked to on probation [is that] probation is not to be dealt with by black people. That's why you see a lot of black guys doing the time instead of taking the probation.

Whereas William indicts probation for unfair treatment, other disadvantaged defendants in my sample focused on the burdensome requirements of probation given the realities of their disadvantaged social ties and neighborhood environments. More than viewing probation as discriminatory, these individuals exhibit a form of legal estrangement (Bell 2017) — or, a marginal relationship with probation given its failures to account for the structural realities of everyday life in poor communities of color. For instance, Richard (B, WC, WC), who was on probation at the time of our interview, recounted to me the difficulties of abiding by the requirements of probation while maintaining everyday relationships with friends and families in his neighborhood. He said:

You have to watch out for anyone doing dumb shit. I can't deal with anybody who's fucking around. I just I watch out for my surroundings too. You know I could end up getting into a fucking fight and that could lead to being in the wrong place at the wrong time $[. .$.$] plus, being a black male, I just understand that you get caught up in a lot of$ stuff even if you don't want even if you don't want to be there. [...] Man, it's crazy, [one time] I was with this dude who was smoking [...] and I stayed away from it, but, you know, I came back and I had a urine and when I took the urine the THC line was kind of slim, kind of light. [...] I don't smoke or nothing but damn second-hand smoke can make that shit light up like that so I'm like, you know, I definitely can't play around with nothing, I can't even be in the vicinity so...

For Richard, "being a black male" — with the possibilities of having to defend himself or get "caught up"-makes him uniquely susceptible to the surveillance of probation. He also recounts how he is unable to be around people who smoke marijuana, lest he have a contact high.

Some poor white defendants also articulated their frustrations with probation, noting the difficulties of maintaining employment and abiding by conditions. Tonya (W/N, P, P), for 
instance, articulated the many burdens of probation that she has experienced. She said that being on probation was "like being in jail"-drawing an equivalence between the two types of sentences. I asked her to tell me more, and she went on to describe probation as "harder" than jail:

Author: How was being on probation basically like being in jail?

Tonya: It's harder

Author: Hmm. Tell me more about that.

Tonya: Um...You can't live a normal life. They put demands on you that are almost impossible. Um...programs, counseling, drug counseling, drug programs...urines, coming in and out of Braintree and Boston and paying for that. Paying for your trips, paying for your fees, paying um...Plus they want you to work. Scheduling all this stuff around your work?! There's nobody going to want to hire you for all that, you know, to schedule you around groups that probation mandates you to do.

The many conditions on Tonya's probation made it difficult to maintain a job, which was yet another condition of her probation. Tonya has had many interactions with probation over her life course, and her many unsuccessful experiences with probation have indelibly shaped her negative perspective on it as an alternative sanction.

Indeed, the preference for choosing incarceration over probation for these defendants was often articulated with reference to prior experiences of alternative sanctions they did not find to be positive; therefore, despite their expressed unwillingness to engage in probation programs, these individuals still participated in them at some point in their lives. It is unclear in my sample how often defendants with this form of legal expertise about probation and other alternatives make legal decisions on the basis of this particular form of expertise. Nevertheless, lawyers' accounts confirm that at least some of their clients do so often enough that some lawyers recognize the possibility of their clients' differential preferences. For instance, a public defender from the Northeast State study described how he, unlike some of his colleagues, always asks his clients "what's your goal after trial if you lose?" He does so because he recognizes that some of his clients prefer to serve time in jail or prison rather than serve time on probation:

To me, it's one of the more important conversations you can have before you get to thatyou have to have it because some people may want to say, "Get me jail time. I don't want to be on probation for the next three years. I'd rather go to jail for four to five months,"

you know? And the factors for that could be many including (sighs) they don't want to be monitored, they don't want to pay the fees, you know... whatever it may be, you know? People don't always want to be out.

Future research could further explore the role of expertise about the realities of abiding by certain sentencing conditions in shaping defendants' preferences and decision-making during sentencing.

\section{Alternative Explanations}

This paper has argued that mistrust shapes defendants' likelihood of withdrawing from their lawyers and acquiring their own forms of legal expertise, often resulting in punitive responses 
from lawyers and the court as well as the constraining of legal choices. One alternative explanation for these findings is that mistrust of and withdrawal from lawyers results from, rather than contributes to, punitive court experiences. There are two variants to this alternative account.

The first variant of this explanation raises an analytic point: Interview-based accounts of mistrust may constitute defendants' post-hoc rationalizations of perceived negative outcomes. In other words, defendants who perceive they received unfair court outcomes may, after the fact, perceive that their lawyer was not trustworthy. Other researchers have noted the difficulty of analyzing defendants' recollections of their former lawyers through reliance on retrospectiveespecially, survey - data (e.g., Boccaccini et al. 2004, p. 209-10). However, this paper's use of ethnographic observational data in addition to in-depth interview data provides a unique advantage. Through ethnographic evidence, I have shown moments when mistrust and trust precede and shape defendants' cultural styles in real time; recall the in-depth descriptions of Arnold (B, WC, MC) and Tonya's (W/N, P, P) experiences at the beginning of the findings section. Moreover, the order and process of questioning in the in-depth interview as described in the research design section afforded my respondents the opportunity to explain their recollections of their interactions with their attorneys in sequential order. This design allowed us - me as the interviewer and defendants as respondents - to clarify in the interview setting when and why respondents remembered beginning to trust or mistrust their lawyers and how their views influenced their decisions.

The second variant of this alternative explanation suggests a missing component of the process: A defendant who mistrusts his or her lawyer may be represented by a lawyer whose knowledge of criminal law or procedure is ineffective or who is unwilling to exercise his or her client's due process rights. Indeed, as I have shown, many defendants in my sample suggest that their lawyers are ineffective along these very dimensions. My data, however, cannot describe the objective quality of each respondent's lawyer (see e.g., Anderson and Heaton 2012). This paper instead considers whether and how defendants' perceptions of their lawyers influence their cultural styles and decision-making. Rather than being an alternative explanation, the possibility that untrustworthy lawyers may also be less effective lawyers should be understood as complementary. My findings reveal the criteria by which less effective defense attorneys may decide to differentially allocate their scarce legal resources among their clients. Overwhelmed court-appointed lawyers may selectively advocate for the clients who delegate authority to them and ignore or punish those who withdraw and seek to use their self-acquired expertise (on selective advocacy in general, see Emmelman 1994, Van Cleve 2016; but also see Flemming 1986 on the paradox of "client control"). All else equal, a trusting relationship appears to garner relatively better advocacy from lawyers and enables less fraught interaction with other legal officials, such as judges, and the court process more broadly.

\section{DISCUSSION}

While scholars have considered how criminal laws and the discretionary decision-making of legal officials influence defendants' court outcomes, defendants nevertheless are faced with numerous difficult decisions of their own as they are processed through the courts. How do they make such decisions, and to what effect? By considering the experiences of a diverse sample of criminal defendants in the Boston area, this paper described the cultural styles and cultural resources defendants employ. I revealed how defendants who have reason to trust their lawyers 
often delegate legal authority to them in consequential decision-making moments and experience relative ease of court navigation as a result, whereas defendants who have reason to mistrust their lawyers often withdraw from lawyers and seek to acquire their own legal expertise, such as knowledge about criminal law and procedure learned in their communities, in jail, and through observation. Defendants' use of self-acquired expertise often incurs punitive responses from legal officials and constrains defendants' legal choices, given the everyday realities of alternative sanctions in the lives of people living in poor, highly-surveilled neighborhoods. I also revealed how these processes often work to the detriment of less-advantaged defendants, given their lack of access to lawyers they trust and skepticism of legal officials' incentives. These findings have implications for research on criminal court disparities and sociological theory on culture, expertise, and navigation across a range of institutions.

\section{Differential Navigation and Disparities}

Findings have implications for explanations of race and class disparities in criminal court outcomes. Existing sociological and criminological research suggests that race and class differences in charging, bail, and sentencing outcomes can be explained by numerous interacting factors, including the legal charge, the nature of the offense, the criminal record, the competence of legal representation, and the race or class-based biases and discriminatory behaviors of legal officials (see Baumer 2013; Clair and Winter 2016; Spohn 2000; Ulmer 2012). In addition to these existing explanations, this paper suggests two additional and complementary factors: (1) differential cultural styles (i.e., legal officials' punitive responses to the cultural style of withdrawal and to the use of self-acquired legal expertise outside the attorney-client relationship); and, (2) differential preferences (i.e., the process by which self-acquired expertise about the everyday realities of surveillance among defendants living in, or with social ties to, highly-surveilled, majority-minority neighborhoods constrain their abilities to choose relatively less-punitive alternative sentences such as probation). These two factors constitute the broader process of differential navigation, which likely contributes to disparate formal legal outcomes.

Figure 1 summarizes the mechanisms constituting the process of differential navigation uncovered in this paper. Whereas differential preferences operating through constrained legal choices are directly related to living in, or having social ties to individuals who live in, highlysurveilled, poor neighborhoods, the cultural styles of delegation and withdrawal also appear to be shaped by inequality in class- and race-based resources but mediated through the perceived trustworthiness of attorneys. In other words, access to social and economic resources-often less available to working-class, poor, and racial/ethnic minority defendants - enables the forming of trusting attorney-client relationships (see Levine 2013 on social disadvantage and distrust among low-income women). Less-advantaged defendants in my sample recount negative experiences with lawyers and other legal officials, frustration at being unable to hire a lawyer outside of the indigent defense system, and perceptions that court-appointed lawyers have misaligned incentives; meanwhile, their advantaged peers largely recount faith in their lawyers, many of whom were acquired through trusted social ties. Although my sample is not representative, patterns of mistrust in other legal contexts such as policing have documented similar race and class differences (see Bobo and Thompson 2006; Hagan and Albonetti 1982; Muller and Schrage 2014). ${ }^{19}$

\footnotetext{
${ }^{19}$ Researchers have also found high rates of mistrust in lawyers among samples of incarcerated individuals (see Boccaccini et al. 2004; Casper 1972); yet, this work does not provide insight into race and class differences.
} 
[Figure 1 here]

By illuminating how the institutional rules of the criminal courts punish certain cultural styles and shape differential preferences, the process of differential navigation underscores how race and class inequalities are fundamental to the process. Whereas much existing research on legal officials' biases and discriminatory behaviors might suggest that disparities could be solved through implicit bias training or by removing "bad apples" from the profession, this paper reveals that such individual-level changes would likely be insufficient. Extending Van Cleve's (2016) study of the Cook County, Illinois courts, where she describes the racialized "charade" of due process rights, this paper uncovers the differential ways the exercise of such rights is leveraged, rewarded, and punished. For a fairer system, the court must acknowledge lessadvantaged defendants' legitimate reasons for mistrusting lawyers, accommodate their attempts to use their self-acquired legal expertise, and provide the conditions to mitigate the punitive costs of alternative sentences in their lives. Some scholars have suggested ways individual lawyers may be able to establish trusting relationships with their clients (see Boccaccini and Brodsky 2001), such as through a client-centered approach to legal representation (Uphoff 2000; Uphoff and Wood 1998). In addition, institution-level changes could include affording indigent defendants choice in lawyers (but see Schulhofer and Friedman 1993 on practical and legal limitations), establishing alternative criminal courts that handle only pro se cases thereby providing defendants with a more coherent alternative to the professionalized process, establishing informed consent doctrines similar to the medical field (Spiegel 1979), and developing procedures that account for neighborhood residence and social ties when tailoring alternative sentences.

Future research could further examine how, why, and with what consequences cultural styles interact with the court's implicit and explicit institutional rules. While this paper offers a first step at examining the role of defendants' cultural resources and styles in shaping court processing, a handful of existing studies have observed that defendants' cultural attitudes are associated with disparate outcomes. For instance, Mears et al. (2017) find that black defendants who express adherence to a "code of the street" culture are more likely to be arrested and convicted than their same-race peers who do not adhere to such a culture. The authors suggest that more research should investigate the expressive and micro-interactional processes that explain such an association (Mears et al. 2017, pp. 239-40). Moreover, in their study of the use of alternative sanctions in the Pennsylvania court system, Johnson and DiPietro (2012) find that judges are less likely to afford racial/ethnic minorities (specifically blacks and Hispanics) alternative sanctions to incarceration than their peers, all else equal. The authors posit that (but do not examine whether) "offender agency," or "willingness to participate in intermediate punishment programs," may partly explain their results (Johnson and DiPietro 2012, p. 837-8). My findings extend existing literature on cultural attitudes by examining cultural styles of behavior and by revealing how differences in both attitudes and styles are rooted in race- and class-based inequalities in resources and trust, thereby likely reproducing inequality along these very lines. Using Figure 1 as a guide, future research could pair administrative court data with detailed survey or observational data on defendants' styles and uses of legal expertise, allowing for the testing of counterfactual causal hypotheses regarding the proportion of race or class variation in different outcomes that can be explained by differential styles or preferences. 


\section{Culture, Expertise, and Institutional Navigation}

Findings also have implications for sociological theory on culture, expertise, and institutional navigation more broadly. As noted earlier, cultural sociologists have often differentiated between two general kinds of cultural forms - cultural resources and cultural styles (see e.g., Lizardo 2017; Patterson 2014; Sewell 1992). In this paper, I have revealed the way one cultural resource (in this case, legal expertise) and two cultural styles (in this case, delegation/reliance on lawyers' authority versus withdrawal from lawyers' authority and reliance on one's own expertise) intertwine and influence defendants' court experiences. Findings relating to each of these cultural forms have implications for understanding the reproduction of inequality across a range of institutions.

First, with respect to cultural styles and institutional navigation, my findings show that the cultural styles that reproduce inequality are institution-specific. The institutional rules of the courts implicitly require individuals to engage in a cultural style of delegation and deference- $-\mathrm{a}$ style that other scholars have shown does not reap rewards in other institutions. While the theoretical idea that different institutions might require different styles of engagement has been articulated before (e.g., Sewell 1992), cultural sociologists have tended to suggest that the same general disposition allows for an ease of navigation across various institutional spaces (Bourdieu 1990 [1980]; Lareau 2015; Shim 2010; Stephens et al. 2013; see also Sewell 1992 on the transposability of schemas). Yet, comparing existing research on the navigation of schools - a commonly studied institutional space - to that of courts underscores how cultural styles that accrue profits in schools rarely allow for successful navigation in the courts. In schools, Lareau (2011, 2015) and others (e.g., Calarco 2014; Streib 2011) have shown how middle-class parents and students reproduce their advantage through their proactive, exacting, and demanding interactions with teachers and other authorities - accruing more class time (Streib 2011), exemptions from homework (Calarco 2014), and other accommodations, such as placement in higher level courses (Lareau 2011). Moreover, Calarco (2014) shows how working-class parents' deference toward, and trust in, teachers as experts negatively impacts their children's classroom and problem-solving strategies. By contrast, in the criminal courts, I find that it is lessadvantaged individuals who are more demanding and questioning of lawyers and of the court system more broadly - but to their detriment. Meanwhile, delegation and deference in the courts are cultural styles that often result in relatively lighter punishments among the socioeconomically advantaged.

In addition, my findings reveal that cultural styles are not necessarily stable across the life course, at least not in the courts. Lareau (2015) shows how the sense of entitlement that middle-class children learn from their parents translates into their assertive negotiation of institutions into adulthood (see also Bourdieu 1990 [1980] on habitus); yet, the experience of Arnold (B, WC, MC) highlights the situationally-dependent nature of cultural styles, which can vary within the same individual depending on the social context the individual faces. Arnold's willingness to delegate authority to his second lawyer but not his first reveals how immediate access to social and economic resources and finding a trustworthy lawyer can allow for the opposite cultural style. While some scholars have argued that cultural styles and dispositions can be gradually altered through new life experiences (see e.g., Horvat and Davis 2011), my findings reveal how some cultural styles are not only gradually mutable but also situationally-dependent, fleeting, and even strategic, from the perspective of the social actor. Perhaps the relative rarity of criminal court involvement in the average person's life course (as opposed to the regularity of 
involvement in schools or workplaces) partly explains the situationally-dependent and variable nature of an individual's cultural styles in the courts.

Future research could consider how cultural styles operate similarly or differently in other punitive institutions. This research could examine how specific institutional rules reward unique cultural styles - and the extent to which such styles shape unequal race or class outcomes. As various legal techniques of social control and criminalization continue to expand and morph across numerous institutional spaces in American society, ${ }^{20}$ a greater number of people from different race and class backgrounds have come to experience penal techniques of social control - from police encounters and arrest to court processing, probation, and deportation (DeMichele 2014; Kohler-Hausmann 2013; Phelps 2016). And in the face of budget cuts and the general trend toward the devolution of punitive control from the state to private institutions (Miller 2014; see also Wacquant 2010), various local organizations (e.g., sober houses, needle exchanges, prisoner re-entry organizations, homeless shelters) and existing governmental agencies (e.g., welfare offices) have faced growing caseloads. In many of these institutions, individuals/clients must interact with professionals and bureaucrats who control the extent to which they can avoid myriad legal, political, and civic penalties (Lipsky 1980; Miller 2014; Soss 2005).

How do socio-economically advantaged individuals engage with, and learn from, contact with punitive institutions in comparison to less-advantaged individuals? How might different ways of navigating these institutions contribute to the reproduction of race and class inequalities? These questions could motivate future research in an era of increasing criminalization across various domains. As noted in the beginning of this paper, much has been written on punitive institutions from the perspective of the poor, but rarely do researchers undertake a comparison of individuals with varying levels of resources. Reich's (2005) study of parents engaging with Child Protective Services (CPS) is an exception. Although she does not expressly theorize race and class inequalities, her findings speak to the way distinct cultural styles are rewarded and others punished. In one chapter, she describes how a middle-class black woman with various forms of resources ultimately loses her children to the state because she does not exhibit deference (see also Harris 2009 on expectations of deference to judges in juvenile probation hearings). My findings regarding delegation and deference in the attorney-client relationship are perhaps even more drastic, given that lawyers are professionally designated to protect defendants' due process rights, whereas case workers in CPS are investigators, analogous to the police or prosecutors in the criminal law.

Second, with respect to cultural resources, my findings have implications for sociological understandings of how professionals and everyday people contest and struggle over the resource of expertise in consequential moments. In particular, my findings show how the efficacy of legal expertise is deeply dependent on legitimation by professional authorities and institutions, unlike other forms of expertise. Sewell (1992) argues that the power of resources, such as cultural knowledge, can depend on the status of the actors wielding such resources. Similarly, sociologists of expertise have differentiated between substantive expertise (i.e., knowledge about how to solve a problem) and relational expertise (i.e., the relationships between actors legitimated as experts that allows them to coordinate to solve problems) (Collins and Evans 2007). In civil proceedings, the relational expertise of professionals has been shown to explain much of the advantage of lawyers in comparison to pro se litigants (Sandefur 2015). In the

\footnotetext{
${ }^{20}$ Beyond the more than two million individuals incarcerated in prisons and jails today in our country, nearly 4.7 million people were on probation or parole in 2015 (Kaeble and Glaze 2016).
} 
criminal courts, I have shown how a defendant's acquisition of knowledge about the criminal law and criminal procedure cannot be employed without the mediation and legitimation of one's lawyer. Both substantive and relational expertise about the criminal courts matter in this process, but it is a lawyer's relational expertise with the court that ultimately makes substantive expertise effective. These findings offer important insight into broader debates in cultural sociology about the role of cultural knowledges versus cultural styles in reproducing inequality (see Gaddis 2013; Lizardo 2017).

Findings about expertise in the criminal courts have implications across-and could spark research into the nature of expertise as a cultural resource in navigating - a range of other institutions (see Shim 2010 on theorizing cultural capital in health care institutions). The lawyerclient relationship has its analogues, including the doctor-patient, professor-graduate student, social worker-client, case worker-welfare recipient, border agent-immigrant relationships. Each of these relationships involves a professional, with legitimated control over the expertise necessary to solve certain problems (Abbott 1988). Whether they be social (e.g., an accusation of welfare fraud) or bodily (e.g., a diagnosis of hypertension) problems, they are channeled and structured by professionals serving as mediators between a client with a problem and an institution managing the problem. Professionals must advocate, or not, on behalf of their clients in the face of administrative authorities such as judges, hospitals, health insurers, university administrators, and other higher-level bureaucrats (Haug and Sussman 1969; Lipsky 1980; Shim 2010). Whereas social problems likely rely more so on relational expertise than do bodily problems (which require substantive expertise about the relatively-predictable chemical and physical properties of the natural world) (Collins and Evans 2007), both kinds of problems come to be adjudicated, resolved, and managed within institutions.

Nearly half a century ago, Haug and Sussman (1969) described how professional authority was increasingly being challenged by collective "revolts" of clients across myriad institutions, from elementary schools in low-income neighborhoods to hospitals serving longterm patients. Later, Haug (1972) would predict that, with everyday people's increasing access to education and technologies allowing for individuals to acquire their own forms of expertise, clients would increasingly mistrust and contest professionals' authority. Sociologists of expertise have sounded similar warnings (Collins and Evans 2007), especially with respect to natural scientists and scientific expertise in our contemporary political moment of "alternative facts." Yet, my findings reveal that while less-advantaged defendants in the courts often contest professional expertise and seek to acquire their own, their resistance often results in punishment at the individual level. To be sure, defendants may gain dignity by contesting the definition of their crimes or by seeking to file their own motions or by refusing alternative sanctions (see Rios 2011 on black and Latino youths' disrespect toward probation officers as attempts to maintain dignity). Still, a major cost is the punitive responses of their lawyers and the court. Legal officials continue to wield immense power over clients in the courts, rewarding those who exhibit legitimated cultural styles and proper recognition of professional authority and punishing those who do not. Much of the power of legal officials in the criminal courts derives from the state's ultimate authority to enact violence against its subjects. It remains an important empirical question whether-and with what differential consequences-lay expertise is able to contest the authority of professionals in other institutions. 


\section{REFERENCES}

Abbott, Andrew. 2014. The system of professions: An essay on the division of expert labor. University of Chicago Press.

Abel, Laura K. 2006. "A Right to Counsel in Civil Cases: Lessons from Gideon v. Wainwright." Temple Political and Civil Rights Law Review 15(3):527-56.

Anderson, James M., and Paul Heaton. 2012. "How much difference does the lawyer make: The effect of defense counsel on murder case outcomes." Yale Law Journal 122: 154-217.

Baldus, David C., Charles A. Pulaski Jr., and George Woodworth. 1986. "Arbitrariness and discrimination in the administration of the death penalty: A challenge to state supreme courts." Stetson Law Review 15:133-261.

Barley, Stephen R. 1996. "Technicians in the Workplace: Ethnographic Evidence for Bringing Work into Organizational Studies.” Administrative Science Quarterly 41(3):404-41.

Baumer, Eric P. 2013. "Reassessing and Redirecting Research on Race and Sentencing." Justice Quarterly 30(2):231-61.

Bell, Monica C. 2017. "Police reform and the dismantling of legal estrangement." Yale Law Journal 126:2054-2150.

Black, Donald. 1989. Sociological Justice. New York: Oxford University Press.

Blumberg, Abraham S. 1967. Criminal Justice. Chicago: Quadrangle.

Bobo, Lawrence D., and Victor Thompson. 2006. "Unfair by design: The war on drugs, race, and the legitimacy of the criminal justice system." Social Research 73:445-72.

Boccaccini, Marcus T., Jennifer L. Boothby, and Stanley L. Brodsky. 2004. "Development and effects of client trust in criminal defense attorneys: Preliminary examination of the congruence model of trust development." Behavioral sciences \& the law 22 (2): 197214.

Boccaccini, Marcus T., and Stanley L. Brodsky. 2001. "Characteristics of the ideal criminal defense attorney from the client's perspective: Empirical findings and implications for legal practice." Law \& Psychology Review 25: 81.

Bourdieu, Pierre. 1987. Distinction: A Social Critique of the Judgement of Taste. Cambridge, MA: Harvard University Press.

Bourdieu, Pierre. 1990 [1980]. The Logic of Practice. Palo Alto, CA: Stanford University Press.

Bourdieu, Pierre, and Jean-Claude Passeron. 1977. Reproduction in Education, Society and 
Culture. Beverly Hills, CA: Sage.

Braithwaite, John. 1989. Crime, Shame and Reintegration. New York, NY: Cambridge University Press.

Bridges, George S., and Sara Steen. 1998. "Racial disparities in official assessments of juvenile offenders: Attributional stereotypes as mediating mechanisms." American Sociological Review 63(4): 554-570.

Brooks, Richard R. W., and Haekyung Jeon-Slaughter. 2001. "Race, Income, and Perceptions of the U.S. Court System.” Behavioral Sciences \& the Law 19 (2): 249-64.

Calarco, Jessica McCrory. 2014. "Coached for the Classroom Parents' Cultural Transmission and Children's Reproduction of Educational Inequalities." American Sociological Review 79(5):1015-37.

Carter, Prudence L. 2003. “'Black' Cultural Capital, Status Positioning, and Schooling Conflicts for Low-Income African American Youth.” Social Problems 50 (1): 136-55.

Casper, Jonathan D. 1972. American Criminal Justice: The Defendant's Perspective. Englewood Cliffs, NJ: Prentice Hall.

Chiricos, T. G., \& Bales, W. 1991. "Unemployment and punishment: An empirical assessment." Criminology 29:701-723.

Collins, Harry, and Robert Evans. 2007. Rethinking expertise. Chicago, IL: University of Chicago Press.

Collins, Randall. 1981. "On the microfoundations of macrosociology." American Journal of Sociology 86(5): 984-1014.

Cook, Karen S. 2005. "Networks, norms, and trust: The social psychology of social capital." Social Psychology Quarterly 68(1):4-14.

Clair, Matthew. 2018. "Privilege and Punishment: Unequal Experiences of Criminal Justice." Ph.D. Dissertation, Department of Sociology, Harvard University.

Clair, Matthew and Alix S. Winter. 2016. "How judges think about racial disparities: Situational decision-making in the criminal justice system." Criminology 54(2): 332-359.

Cruz, Franklin, M. Elaine Borakove, and Aimee Wickman. 2014. "A Study of the Expansion of the Committee for Public Counsel Services' Representation of the Indigent.” The Justice Management Institute.

D'Alessio, Stewart J., and Lisa Stolzenberg. 1993. "Socioeconomic Status and the Sentencing of the Traditional Offender." Journal of Criminal Justice 21(1):61-77. 
DeMichele, Matthew. 2014. "Studying the community corrections field: Applying neoinstitutional theories to a hidden element of mass social control." Theoretical Criminology 18(4): 546-564.

Demuth, Stephen. 2003. "Racial and Ethnic Differences in Pretrial Release Decisions and Outcomes: A Comparison of Hispanic, Black, and White Felony Arrestees." Criminology 41: 873 .

Demuth, Stephen, and Darrell Steffensmeier. 2004. The impact of gender and race-ethnicity in the pretrial release process. Social Problems 51(2): 222-242.

Du Bois, W. E. B. 1996 [1899]. The Philadelphia Negro: A Social Study. Philadelphia, PA: University of Pennsylvania Press.

Duck, Waverly. 2015. No way out: Precarious living in the shadow of poverty and drug dealing. Chicago: University of Chicago Press.

Eisenhardt, Kathleen M. 1989. "Building theories from case study research.” Academy of Management Review 14(4): 532-550.

Eisenstein, James, and Herbert Jacob. 1977. Felony Justice: An Organizational Analysis of Criminal Courts. Boston, MA: Little, Brown.

Emmelman, Debra S. 1994. "The Effect of Social Class on the Adjudication of Criminal Cases: Class-Linked Behavior Tendencies, Common Sense, and the Interpretive Procedures of Court-Appointed Defense Attorneys.” Symbolic Interaction 17 (1): 1-20.

Ewick, Patricia and Susan S. Silbey. 1998. The Common Place of Law: Stories from Everyday Life. Chicago: University of Chicago Press.

Fagan, Jeffrey, Anthony A. Braga, Rod K. Brunson, and April Pattavina. 2015. "An analysis of race and ethnicity patterns in Boston Police Department field interrogation, observation, frisk, and/or search reports." ACLU of Massachusetts and Boston Police Department. Retrieved at http://raceandpolicing.issuelab.org/resources/25203/25203.pdf

Feeley, Malcolm M. 1992 [1979]. The Process Is the Punishment. New York: Russell Sage Foundation.

Flemming, Roy B. 1986. "Client Games: Defense Attorney Perspectives on Their Relations with Criminal Clients." Law \& Social Inquiry 11 (2): 253-77.

Gaddis, S. Michael. "The influence of habitus in the relationship between cultural capital and academic achievement." Social Science Research 42(1): 1-13.

Galanter, Marc. 1974. "Why the 'Haves' Come out Ahead: Speculations on the Limits of Legal 
Change." Law \& Society Review 9(1):95-160.

Glaser, Barney G., and Anselm L. Strauss. 1967. The discovery of grounded theory: Strategies for qualitative research. New York: Aldine.

Goffman, Alice. 2014. On the Run: Fugitive Life in an American City. University of Chicago Press.

Goffman, Erving. 1967. Interaction ritual: Essays in face to face behavior. Garden City, NY: Doubleday.

Gurley, Gabrielle. 2014. "Public Defender Blues." CommonWealth, January 15. Retrieved at: http://commonwealthmagazine.org/uncategorized/004-public-defender-blues/

Hagan, John \& Celesta Albonetti. 1982. "Race, Class, and the Perception of Criminal Injustice in America," American Journal of Sociology 88:329-55.

Harris, Alexes. 2009. "The role of power in shaming interactions: how social control is performed in a juvenile court." Contemporary Justice Review 12(4): 379-399.

Haug, Marie R. 1972. "Deprofessionalization: an alternate hypothesis for the future." The Sociological Review 20(1): 195-211.

Haug, Marie R., and Marvin B. Sussman. 1969. "Professional Autonomy and the Revolt of the Client." Social Problems 17(2):153-61.

Heumann, Milton. 1981. Plea bargaining: The experiences of prosecutors, judges, and defense attorneys. Chicago: University of Chicago Press.

Horvat, Erin McNamara, and James Earl Davis. 2011. "Schools as sites for transformation: Exploring the contribution of habitus." Youth \& Society 43(1): 142-170.

Jack, Anthony A. Forthcoming. The Privileged Poor: How Elite Colleges Are Failing Disadvantaged Students. Cambridge, MA: Harvard University Press.

Johnson, Brian D. 2003. "Racial and ethnic disparities in sentencing departures across modes of conviction." Criminology 41:449-90.

Johnson, Brian D. 2006. "The Multilevel Context of Criminal Sentencing: Integrating Judge- and County-Level Influences.” Criminology 44(2):259-298.

Johnson, Brian D., and Stephanie M. DiPietro. 2012. "The power of diversion: Intermediate sanctions and sentencing disparity under presumptive guidelines." Criminology 50(3): $811-850$.

Kaeble, Danielle and Lauren Glaze. 2016. Correctional Populations in the United States, 2015. 
Washington, DC: U.S. Department of Justice, Bureau of Justice Statistics.

Kohler-Hausmann, Issa. 2013. "Misdemeanor Justice: Control without Conviction.” American Journal of Sociology 119(2):351-93.

Kutateladze, Besiki L., Nancy R. Andiloro, Brian D. Johnson, and Cassia C. Spohn. 2014.

"Cumulative Disadvantage: Examining Racial and Ethnic Disparity in Prosecution and Sentencing." Criminology 52(3):514-51.

Kritzer, Herbert Morris. 1998. Legal Advocacy: Lawyers and Nonlawyers at Work. Ann Arbor: University of Michigan Press.

Lamont, Michèle, and Annette Lareau. 1988. "Cultural Capital: Allusions, Gaps and Glissandos in Recent Theoretical Developments.” Sociological Theory 6(2):153.

Lamont, Michèle, Stefan Beljean, and Matthew Clair. 2014. "What Is Missing? Cultural Processes and Causal Pathways to Inequality." Socio-Economic Review 12(3):573-608.

Lareau, Annette. 2015. “Cultural Knowledge and Social Inequality.” American Sociological Review 80(1):1-27.

Lareau, Annette. 2011. Unequal childhoods: Class, race, and family life. University of California Press.

Levine, Judith. 2013. Ain't no trust: How bosses, boyfriends, and bureaucrats fail low-income mothers and why it matters. Oakland, CA: University of California Press.

Lipsky, Michael. 1980. Street-Level Bureaucracy: Dilemmas of the Individual in Public Services. New York: Russell Sage Foundation.

Lizardo, Omar. 2017. "Improving cultural analysis: considering personal culture in its declarative and nondeclarative modes.” American Sociological Review 82(1): 88-115.

Lynch, Mona. 2016. Hard Bargains: The Coercive Power of Drug Laws in Federal Court. New York, NY: Russell Sage Foundation.

Martin, Jamie S., Kate Hanrahan, and James H. Bowers Jr. 2009. "Offenders' perceptions of house arrest and electronic monitoring." Journal of offender rehabilitation 48(6): 547570.

Mather, Lynn M. 1979. Plea Bargaining or Trial? The Process of Criminal-Case Disposition. Lexington, MA: Lexington Books.

Mather, Lynn. M. 2003. "What Do Clients Want-What Do Lawyers Do.” Emory LJ, 52, 1065.

Mears, Daniel P., Eric A. Stewart, Patricia Y. Warren, and Ronald L. Simons. 2017. "Culture and 
formal social control: The effect of the code of the street on police and court decisionmaking." Justice Quarterly 34 (2): 217-247.

Miller, Reuben Jonathan. 2014. "Devolving the carceral state: Race, prisoner reentry, and the micro-politics of urban poverty management." Punishment \& Society 16(3): 305-335.

Mitchell, Ojmarrh. 2005. "A meta-analysis of race and sentencing research: Explaining the inconsistencies." Journal of Quantitative Criminology 21:439-66.

Morris, Norval, and Michael Tonry, 1991. Between prison and probation: Intermediate punishments in a rational sentencing system. Oxford University Press.

Muller, Christopher, and Daniel Schrage. 2014. "Mass imprisonment and trust in the law." The ANNALS of the American Academy of Political and Social Science 651(1): 139-158.

Natapoff, Alexandra. 2005. "Speechless: The silencing of criminal defendants." NYUL Rev. 80: 1449.

Nobiling, Tracy, Cassia Spohn, and Miriam DeLone. 1998. "A Tale of Two Counties: Unemployment and Sentence Severity.” Justice Quarterly 15(3): 459-85.

O'Brien, Stewart, Steven Pheterson, Michael Wright, and Carl Hostica. 1977. "The criminal lawyer: The defendant's perspective." Am. J. Crim. L. 5: 283.

Pager, Devah, and Hana Shepherd. 2008. The sociology of discrimination: Racial discrimination in employment, housing, credit, and consumer markets. Annual Review of Sociology 34:181-209.

Patterson, Orlando. 2014. "Making sense of culture." Annual Review of Sociology 40: 1-30.

Petersilia, Joan. 1990. "When probation becomes more dreaded than prison." Fed. Probation 54: 23.

Petersilia, Joan, and Elizabeth Piper Deschenes. 1994. "Perceptions of punishment: Inmates and staff rank the severity of prison versus intermediate sanctions." The Prison Journal, 74(3): 306-328.

Phelps, Michelle S. 2016. "Mass Probation: Toward a More Robust Theory of State Variation in Punishment." Punishment \& Society.

Reich, Jennifer A. 2005. Fixing families: Parents, power, and the child welfare system. New York, NY: Routledge.

Ridgeway, Cecilia L. 2014. "Why status matters for inequality." American Sociological Review 79 (1): 1-16. 
Rios, Victor M. 2011. Punished: Policing the lives of Black and Latino boys. New York: NYU Press.

Rivera, Lauren A. 2015. Pedigree: How elite students get elite jobs. Princeton University Press.

Sandefur, Rebecca L. 2015. "Elements of Professional Expertise: Understanding Relational and Substantive Expertise through Lawyers' Impact." American Sociological Review 80(5): 909-33.

Schlesinger, Traci. 2005. "Racial and Ethnic Disparity in Pretrial Criminal Processing." Justice Quarterly 22(2):170-92.

Schulhofer, Stephen J., and David D. Friedman. 1993. "Rethinking indigent defense: promoting effective representation through consumer sovereignty and freedom of choice for all criminal defendants." Am. Crim. L. Rev. 31 (1993): 73.

Sellin, Thorsten. 1928. "The Negro Criminal. A Statistical Note.” The Annals of the American Academy of Political and Social Science 140: 52-64.

Sewell, William H., Jr. 1992. "A Theory of Structure: Duality, Agency, and Transformation.” American Journal of Sociology 98 (1): 1-29.

Shermer, Lauren O’Neill, and Brian D. Johnson. 2010. “Criminal Prosecutions: Examining Prosecutorial Discretion and Charge Reductions in U.S. Federal District Courts." Justice Quarterly 27 (3): 394-430.

Shim, Janet K. 2010. "Cultural health capital: a theoretical approach to understanding health care interactions and the dynamics of unequal treatment." Journal of Health and Social Behavior 51(1): 1-15.

Silbey, Susan S. 2005. “After Legal Consciousness.” Annual Review of Law and Social Science 1(1):323-68.

Small, Mario Luis. 2009. “'How Many Cases Do I Need?' On Science and the Logic of Case Selection in Field-Based Research.” Ethnography 10(1):5-38.

Smith, Sandra Susan. 2010. "Race and trust.” Annual Review of Sociology 36: 453-475.

Soss, Joe. 2005. "Making Clients and Citizens: Welfare Policy as a Source of Status, Belief, and Action" In Deserving and Entitled: Social Constructions and Public Policy, edited by A. L. Schneider and H. M. Ingram. Albany, NY: SUNY Press.

Spelman, William. 1995. "The severity of intermediate sanctions.” Journal of Research in Crime and delinquency 32(2): 107-135.

Spiegel, Mark. 1979. "Lawyering and Client Decisionmaking: Informed Consent and the Legal 
Profession." University of Pennsylvania Law Review 128(1): 41-140.

Spohn, Cassia C. 2000. Thirty years of sentencing reform: The quest for a racially neutral sentencing process. In Policies, Processes, and Decisions of the Criminal Justice System, vol. 3, edited by J. Horney. Washington, DC: National Institute of Justice.

Spohn, Cassia C. 2013. "Racial disparities in prosecution, sentencing, and punishment." In The Oxford Handbook of Ethnicity, Crime, and Immigration, edited by S. M. Bucerius and M. Tonry. Oxford, UK: Oxford University Press.

Spohn, Cassia, John Gruhl, and Susan Welch. 1981. "The Effect of Race on Sentencing: A ReExamination of an Unsettled Question." Law \& Society Review 16(1):71-88.

Steffensmeier, Darrell, Jeffery Ulmer, and John Kramer. 1998. "The Interaction of Race, Gender, and Age in Criminal Sentencing: The Punishment Cost of Being Young, Black, and Male." Criminology 36(4):763-798.

Stephens, Nicole M., Hazel Rose Markus, and L. Taylor Phillips. 2014. "Social Class Culture Cycles: How Three Gateway Contexts Shape Selves and Fuel Inequality." Annual Review of Psychology 65(1):611-34.

Streib, Jessi. 2011. "Class Reproduction by Four Year Olds." Qualitative Sociology 34(2):33752.

Stuart, Forrest. 2016. Down, Out and Under Arrest: Policing and Everyday Life in Skid Row. University of Chicago Press.

Stuart, Forrest, Amada Armenta, and Melissa Osborne. 2015. "Legal control of marginal groups." Annual Review of Law and Social Science, 11: 235-254.

Tonry, Michael 1995. Malign neglect: Race, crime, and punishment in America. Oxford, UK: Oxford University Press.

Tonry, Michael, and Matthew Melewski. 2008. "The Malign Effects of Drug and Crime Control Policies on Black Americans." Crime and Justice 37(1):1-44.

Travis, Jeremy, Bruce Western, and F. Stevens Redburn. 2014. The growth of incarceration in the United States: Exploring causes and consequences. Washington, DC: National Academies Press.

Tyler, Tom R. "The role of perceived injustice in defendants' evaluations of their courtroom experience." Law and Society Review (1984): 51-74.

Ulmer, Jeffery T. 2012. "Recent Developments and New Directions in Sentencing Research." Justice Quarterly 29 (1): 1-40. 
Uphoff, Rodney J. 2000. "Who Should Control the Decision to Call a Witness: Respecting a Criminal Defendant's Tactical Choices." U. Cin. L. Rev. 68: 763.

Uphoff, Rodney J., and Peter B. Wood. 1998. "The Allocation of Decisionmaking Between Defense Counsel and Criminal Defendant: An Empirical Study of Attorney-Client Decisionmaking." U. Kan. L. Rev. 47: 1.

Van Cleve, Nicole Gonzalez. 2016. Crook County: Racism and Injustice in America's Largest Criminal Court. Stanford University Press.

Wacquant, Loïc. 2010. "Class, race \& hyperincarceration in revanchist America." Daedalus 139(3): 74-90.

Weiss, Robert S. 1994. Learning from strangers: The art and method of qualitative interview studies. Free Press.

Wilkerson, Glen. 1972. "Public defenders as their clients see them." Am. J. Crim. L. 1: 141.

Wood, Peter B., and David C. May. 2003. "Racial differences in perceptions of the severity of sanctions: A comparison of prison with alternatives." Justice Quarterly 20(3): 605-631.

Young Jr, Alford A. 1999. "The (non) accumulation of capital: Explicating the relationship of structure and agency in the lives of poor black men." Sociological Theory 17(2): 201227.

Young, Kathryne M. 2014. "Everyone knows the game: Legal consciousness in the Hawaiian cockfight." Law \& Society Review 48(3): 499-530.

Young, Kathryne M., and Christin L. Munsch. 2014. "Fact and Fiction in Constitutional Criminal Procedure.”SCL Rev. 66: 445.

Zatz, Marjorie S. 2000. "The Convergence of Race, Ethnicity, Gender, and Class on Court Decisionmaking: Looking Toward the 21st Century." Criminal Justice 3(1):503-552. 


\section{FIGURES}

Figure 1. The mechanisms undergirding defendants' differential navigation

Race \& class resources

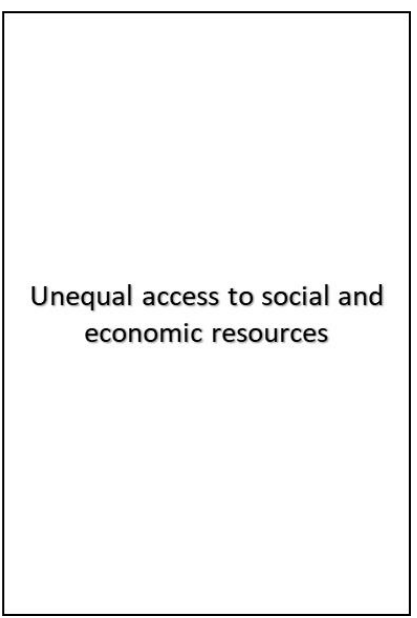

Differential navigation \& decision-making

Disparate experiences

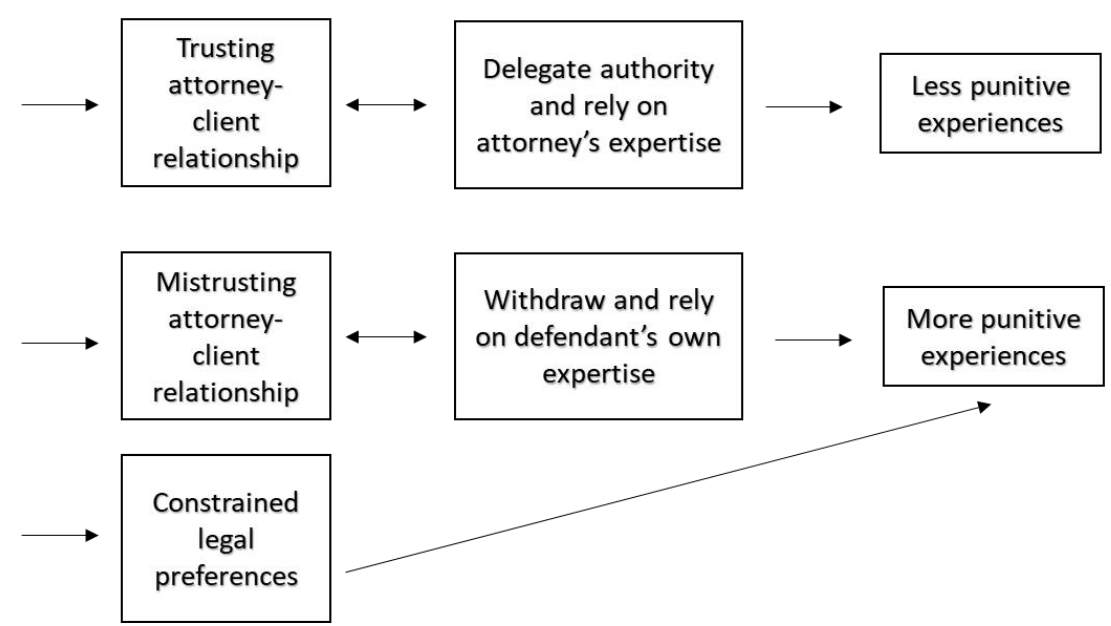




\section{TABLES}

Table 1. Characteristics of defendant interview sample $(\mathrm{N}=49)$

\begin{tabular}{|c|c|}
\hline & $\mathrm{N}(\%)$ \\
\hline \multicolumn{2}{|l|}{ Race/ethnicity* } \\
\hline White & $30(61 \%)$ \\
\hline Black & $17(35 \%)$ \\
\hline Latino/a & $3(6 \%)$ \\
\hline Native American & $1(2 \%)$ \\
\hline \multicolumn{2}{|l|}{ Gender } \\
\hline Male & $42(86 \%)$ \\
\hline Female & $7(14 \%)$ \\
\hline \multicolumn{2}{|l|}{ Educational attainment at interview } \\
\hline Four-year college degree or above & $10(20 \%)$ \\
\hline Some college or associate's degree & $17(35 \%)$ \\
\hline High school degree or GED & $18(37 \%)$ \\
\hline Less than high school degree & $4(8 \%)$ \\
\hline \multicolumn{2}{|l|}{ SES at childhood } \\
\hline Middle class & $19(39 \%)$ \\
\hline Working class & $23(47 \%)$ \\
\hline Poor & $7(14 \%)$ \\
\hline \multicolumn{2}{|l|}{ SES at interview } \\
\hline Middle class & $10(20 \%)$ \\
\hline Working class & $23(47 \%)$ \\
\hline Poor & $16(33 \%)$ \\
\hline \multicolumn{2}{|l|}{ SES at interview, by race/ethnicity* } \\
\hline \multicolumn{2}{|l|}{ Middle class } \\
\hline White & $6(12 \%)$ \\
\hline Non-white & $4(8 \%)$ \\
\hline \multicolumn{2}{|l|}{ Working class } \\
\hline White & $13(27 \%)$ \\
\hline Non-white & $10(20 \%)$ \\
\hline \multicolumn{2}{|l|}{ Poor } \\
\hline White & $11(22 \%)$ \\
\hline Non-white & $6(12 \%)$ \\
\hline
\end{tabular}

*Total is more than $N$ because of respondents who identify as more than one racelethnicity. 
Table 2. Characteristics of defendants observed in real time $(\mathrm{N}=6)$

\begin{tabular}{|c|c|c|c|c|c|c|}
\hline Name & $\begin{array}{l}\text { Race/ } \\
\text { ethnicity }\end{array}$ & $\begin{array}{l}\text { SES } \\
\text { at childhood }\end{array}$ & $\begin{array}{l}\text { SES } \\
\text { at interview }\end{array}$ & Gender & $\begin{array}{l}\text { Case type } \\
\text { observed in real } \\
\text { time }\end{array}$ & $\begin{array}{l}\text { Case types discussed in } \\
\text { interview }\end{array}$ \\
\hline Tonya & $\begin{array}{l}\text { White/ } \\
\text { Native } \\
\text { American }\end{array}$ & $\begin{array}{l}\text { Poor (Both parents less than HS } \\
\text { education; mother was } \\
\text { unemployed, father lost union job) }\end{array}$ & $\begin{array}{l}\text { Poor (GED completed; out } \\
\text { of work for years, receives } \\
\text { SSI) }\end{array}$ & Female & $\begin{array}{l}\text { Probation violation } \\
\text { (cocaine } \\
\text { possession) }\end{array}$ & $\begin{array}{l}\text { 1. Conspiracy to violate drug } \\
\text { laws; } \\
\text { 2. Probation violation (cocaine } \\
\text { possession) }\end{array}$ \\
\hline Don & Black & $\begin{array}{l}\text { Middle class (College-educated } \\
\text { mother, HS educated step-father; } \\
\text { mother was a secondary school } \\
\text { teacher, step-father worked as an } \\
\text { iron worker) }\end{array}$ & $\begin{array}{l}\text { Working class (Some } \\
\text { college completed; worked } \\
\text { as a janitor until recently } \\
\text { laid off after most recent } \\
\text { arrest) }\end{array}$ & Male & $\begin{array}{l}\text { Distribute or } \\
\text { possess with intent } \\
\text { (cocaine, heroin) } \\
\text { and conspiracy to } \\
\text { violate drug laws }\end{array}$ & $\begin{array}{l}\text { 1. Accessory to robbery; } \\
\text { 2. Distribute or possess with } \\
\text { intent (cocaine, heroin); } \\
\text { 3. Distribute or possess with } \\
\text { intent (cocaine, heroin) and } \\
\text { conspiracy to violate drug laws }\end{array}$ \\
\hline Ryan & White & $\begin{array}{l}\text { Middle class (College-educated } \\
\text { parents; mother was a paralegal, } \\
\text { father was a health insurance } \\
\text { agent) }\end{array}$ & $\begin{array}{l}\text { Middle class (Four-year } \\
\text { college degree; investment } \\
\text { consultant for years but } \\
\text { currently unemployed and } \\
\text { in recovery) }\end{array}$ & Male & Shoplifting & $\begin{array}{l}\text { 1. OUI (alcohol) first offense; } \\
\text { 2. OUI (alcohol) second offense; } \\
\text { 3. Shoplifting }\end{array}$ \\
\hline Brianna & White & $\begin{array}{l}\text { Middle class (College-educated } \\
\text { mother, father less than HS } \\
\text { education; Mother was a registered } \\
\text { nurse, father was a taxi driver) }\end{array}$ & $\begin{array}{l}\text { Working class ( } 2 \text {-year } \\
\text { nursing degree; worked as a } \\
\text { nurse for a decade, } \\
\text { currently a cashier) }\end{array}$ & Female & $\begin{array}{l}\text { OUI (drugs), drug } \\
\text { possession }\end{array}$ & $\begin{array}{l}\text { 1. Drug possession (marijuana); } \\
\text { 2. OUI (alcohol); } \\
\text { 3. OUI (drugs), drug possession }\end{array}$ \\
\hline & & & $\begin{array}{l}\text { Working class (Some } \\
\text { college completed; worked }\end{array}$ & & & \\
\hline Mary & Latina & $\begin{array}{l}\text { Working class (Both parents less } \\
\text { than HS education; Mother was a } \\
\text { house cleaner, father was a } \\
\text { landscaper) }\end{array}$ & $\begin{array}{l}\text { as an administrative } \\
\text { assistant at a hospital until } \\
\text { laid off after most recent } \\
\text { court case) } \\
\text { Middle class (Four-year }\end{array}$ & Female & $\begin{array}{l}\text { Assault and battery } \\
\text { with a dangerous } \\
\text { weapon, disorderly } \\
\text { conduct }\end{array}$ & $\begin{array}{l}\text { 1. Larceny/shoplifting; } \\
\text { 2. Assault and battery with a } \\
\text { dangerous weapon; disorderly } \\
\text { conduct }\end{array}$ \\
\hline Arnold & Black & $\begin{array}{l}\text { Working class (Mother had less } \\
\text { than a HS education; Mother } \\
\text { worked in manufacturing as well } \\
\text { as cooking; Father not present) }\end{array}$ & $\begin{array}{l}\text { college degree; worked odd } \\
\text { jobs after college, currently } \\
\text { a minor league basketball } \\
\text { player) }\end{array}$ & Male & $\begin{array}{l}\text { Gun possession } \\
\text { without a license }\end{array}$ & $\begin{array}{l}\text { 1. Open container violation; } \\
\text { 2. Larceny; } \\
\text { 3. Gun possession without a } \\
\text { license }\end{array}$ \\
\hline
\end{tabular}

